\title{
Singly and doubly modified analogues of C20-epi- salinomycin: A new group of antiparasitic agents against Trypanosoma brucei
}

Dominika Czerwonka $^{a, 1}$, Yzobelle Barcelos ${ }^{b, 1}$, Dietmar Steverding ${ }^{b}$, Aleksandra Cioch $^{a}$, Adam Huczyński ${ }^{a}$, and Michat Antoszczak ${ }^{\mathrm{a}, *}$

a Department of Medical Chemistry, Faculty of Chemistry, Adam Mickiewicz University, Uniwersytetu Poznańskiego 8, 61-614 Poznań, Poland

${ }^{\mathrm{b}}$ Bob Champion Research \& Education Building, Norwich Medical School, University of East Anglia, Norwich, UK

Keywords: Polyether ionophore antibiotics; Allylic hydroxyl $O$-acylation; Stereoselectivity; Regioselectivity; Anti-trypanosomal activity; African trypanosomiasis; Trypanosoma brucei

\section{Corresponding Authors}

* E-mail: michant@amu.edu.pl (M. Antoszczak)

${ }^{1}$ Co-first authors 
Abstract: Polyether ionophores, with $>120$ molecules belonging to this group, represent a class of naturally-occurring compounds that exhibit a broad range of pharmacological properties, including promising activity towards a variety of parasites. In this context, salinomycin (SAL) seems to be interesting, as this ionophore has been found to be active against parasites that are responsible for a number of human and animal diseases. On the other hand, less explored is the investigation into the anti-parasitic activity of SAL derivatives. Recently, we identified $\mathrm{C} 1$ amides and esters of SAL and its analogue, C20-oxosalinomycin, as promising structures for trypanocidal drug candidates. In search for novel compounds effective against African trypanosomes, the synthetic access to a completely new series of C20-epi-salinomycin (compound 2) analogues is described in this paper. This series includes products obtained via derivatisation of either the $\mathrm{C} 1$ carboxyl or the $\mathrm{C} 20$ hydroxyl of $\mathbf{2}$, but also $\mathrm{C} 1 / \mathrm{C} 20$ double modified derivatives. The antitrypanosomal activity as well as the cytotoxic activity of these analogues were evaluated with bloodstream forms of T. brucei and human myeloid HL-60 cells, respectively. It was found that the $\mathrm{C} 20$ single modified derivatives $\mathbf{8 , 1 2}$, and $\mathbf{1 8}$ (C20 decanoate, C20 ethyl carbonate, and C20 allophanate of $\mathbf{2}$, respectively) were the most active compounds in selectively targeting bloodstream-form trypanosomes, with $50 \%$ growth inhibition $\left(\mathrm{GI}_{50}\right)$ values of $0.027-0.043 \mu \mathrm{M}$ and selectivity indices of $165-353$. These results indicate that modification at the C20 position of C20-epi-salinomycin 2 can provide semi-synthetic products with enhanced trypanocidal activity that could be of great value for the development of new drugs to treat African trypanosomiasis. 


\section{Introduction}

Polyether ionophores represent a very important group of biologically active molecules of natural origin that have been commercially used for decades as veterinary antibiotics in several countries, primarily to suppress the growth of $\mathrm{Gram}(+)$ bacteria, but also protozoan parasites responsible for coccidiosis [1-2]. Functionally, ionophores may affect the permeability of the bacterial outer membrane to selected cations, and such perturbation is thought to be the underlining antimicrobial effect of these compounds [3]. In the group of more than 120 structures reported until now, particularly interesting seems to be salinomycin (SAL, Scheme 1) because of its relatively broad range of pharmacological properties, which include not only anti-cancer, but also anti-parasitic activities [4].

In screening studies for molecules with selectivity against cancer stem cells (CSCs), SAL was identified as the most promising agent at reducing small sub-populations of breast cancer cells with stem-like phenotype, with significantly higher (>100-fold) potency than that of the widely used anti-cancer chemotherapeutic paclitaxel [5]. Importantly, when used at relevant doses (200$250 \mu \mathrm{g} \mathrm{kg}^{-1}$ ), SAL was well-tolerated by cancer patients, who generally did not experience any long-term acute adverse effects when treated with the ionophore [6]. SAL was also found to be effective in killing a series of other cancer cells of different origin, including cancer cell lines resistant to standard chemotherapeutic drugs [7]. Of note is that compounds that exhibit significant activity on cancer cells, very often are also active against parasites [8]. Indeed, using in vitro tests, SAL has been identified recently as an agent effective against Trypanosoma brucei [9], a species of parasitic kinetoplastid which is responsible for African trypanosomiasis in humans (sleeping sickness) and animals (nagana disease) [10-12]. 
African trypanosomiasis has regularly and repeatedly affected both the economic and cultural development of Central African societies [13]. While the number of sleeping sickness cases reported annually has declined to $<1000$ in recent years [14], nagana disease still remains a major problem for the rural economy in many endemic African countries. Moreover, the history of African trypanosomiasis has shown that interruption of preventive measures can cause subsequent epidemics of the disease [13]. As the few drugs commonly used for the treatment of African trypanosomiasis are dated, less effective and relatively toxic [15-17], the development of better-tolerated drug candidates is of great importance.

Recently, we have identified various $\mathrm{C} 1$ amides and esters of SAL and its C20-oxo analogue as possible lead compounds for the development of novel anti-trypanosomal agents $[9,18]$. The most promising agents in this series inhibited the growth of bloodstream forms of $T$. bruce $i$ in the nanomolar concentration range $[9,18]$. Furthermore, some of the analogues displayed superior trypanocidal activity, which was much higher than that observed for the parent compound SAL, with $\mathrm{GI}_{50}$ and MIC values comparable to those of suramin, a commonly used medication in the therapy of sleeping sickness $[9,18]$. In addition to their potent anti-parasitic activity, SAL amides and esters obtained via derivatisation of the $\mathrm{C} 1$ carboxyl group have shown activity against drug-sensitive and drug-resistant cancer cells of various origin, which clearly demonstrates the promising therapeutic potential of this class of compounds, especially as they exhibited high selectivity of action (low toxicity on non-tumour cells) [19-22].

In 2016, Wu and co-workers synthesized C20-epi-salinomycin (compound 2, Scheme 1), together with six of its C20 ester analogues, and evaluated these compounds with respect to their in vitro anti-proliferative activity towards colorectal, gastric and triple-negative breast cancer cell lines [23]. Importantly, while $\mathbf{2}$ exhibited similar activity to that of unmodified SAL, its C20-O- 
acylated derivatives were 2-10 times more effective in killing cancer cells [23]. Two C20-epiesters were also found to be more selective in inhibiting cancer cells than SAL [23]. These findings prompted us to examine whether analogues of $\mathbf{2}$ display also increased trypanocidal activity.

Here, we describe the synthetic access to a variety of $O$-acylated derivatives of $\mathbf{2}$, including not only its C20 esters, but also C20 carbonates and C20 carbamates (urethanes), which have been synthesized for the first time (Scheme 1). As SAL derivatives with a chemically modified C1 carboxyl group have been shown to exhibit potent activity towards T. brucei $[9,18]$, we also decided to obtain the respective $\mathrm{C} 1$ amide and ester counterparts of $\mathbf{2}$, together with a completely new series of $\mathrm{C} 1 / \mathrm{C} 20$ double modified analogues by joining together desirable structural features to produce drug candidates with promising trypanocidal activity (Scheme 1). The in vitro trypanocidal and cytotoxic activity of the newly synthesized compounds were evaluated using bloodstream form of $T$. brucei and human myeloid HL-60 cells, respectively. Moreover, the antitrypanosomal mechanism of action of the most trypanocidal analogues was investigated through cell swelling experiments.

\section{Results and discussion}

\subsection{Analogues design and synthesis}

C20-epi-salinomycin 2 (Scheme 1) was synthesized according to the protocol reported by $\mathrm{Wu}$ and co-workers [23]. Briefly, because of the unfavourable conformation of SAL for the Mitsunobu reaction, it was first necessary to 'mask' the $\mathrm{C} 1$ functionality of the starting material by a relatively bulky protecting group [23]. The reaction between SAL and TMSEtOH in the presence of TCFH and DIPEA [24] or DMAP [25] resulted in the formation of C1-protected ester with satisfactory yield. The selective inversion of the $\mathrm{C} 20$ absolute configuration was then 
smoothly carried out in the Mitsunobu reaction, using 4-nitrobenzoic acid as a nucleophile [23]. As the allylic hydroxyl is more reactive than the other two hydroxyl groups, full regioselectivity towards the hydroxyl group at the C20 position was noted without formation of any C9- and/or $\mathrm{C} 28$-substituted side-products. Finally, $\mathrm{K}_{2} \mathrm{CO}_{3}$ was used to hydrolyse the 4-nitrobenzoyl group at the $\mathrm{C} 20$ position to give the key intermediate $\mathbf{1}$ without affecting the $\mathrm{C} 1$ ester moiety [23], while 2 was quantitatively and tracelessly released from its orthogonal masking group with TBAF [24]. The NMR data of product $\mathbf{2}$ were well in line with those found in the reference literature [23].

In the next step, novel derivatives of $\mathbf{2}$ were designed and synthesized based on structurally similar $\mathrm{C} 1$ amides and esters of $\mathbf{S A L}$ that exhibited promising trypanocidal activity in our previous studies $[9,18]$, i.e. propargyl amide $\mathbf{3}$, propargyl ester $\mathbf{4}$, and two esters with hydroxamic acids $\mathbf{5}$ and 6 (Scheme 1). Synthetically, amide 3 was formed in a DCC/HOBt activated reaction with propargylamine (Scheme 1). Depending on the substrate used, the products from the ester series were obtained by two different methods; ester $\mathbf{4}$ was formed through direct alkylation of carboxylate ions, using propargyl bromide and DBU as effective nucleophilic catalyst, while analogues 5 and $\mathbf{6}$ were produced via the DCC/DMAP-activated esterification with the corresponding hydroxamic acids, i.e. benz- and salicylhydroxamic acid, respectively (Scheme 1). 

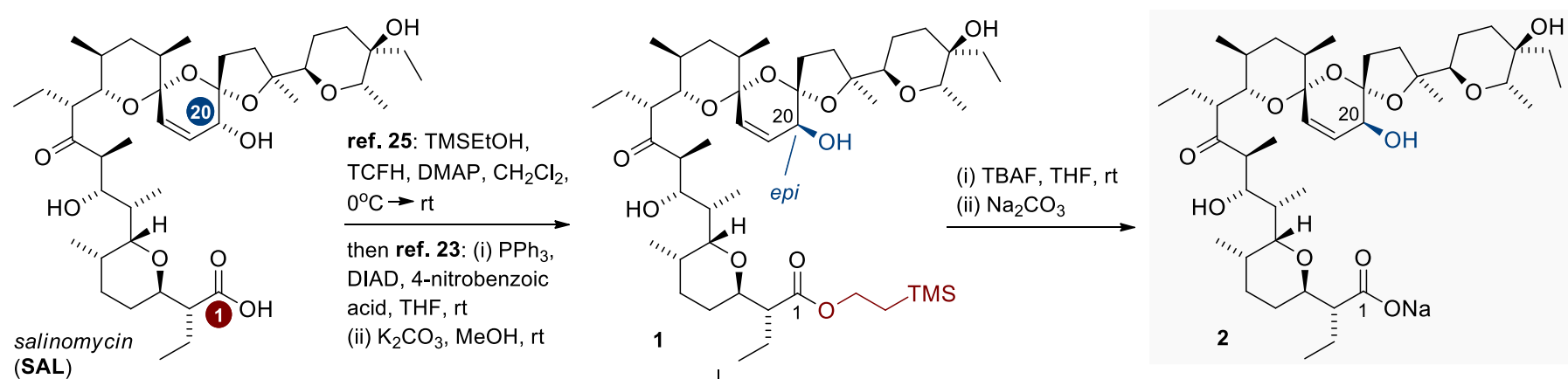

(i) $\mathrm{H}_{2} \mathrm{SO}_{4}$

(ii) for 3: propargylamine, DCC, HOBt, $\mathrm{CH}_{2} \mathrm{Cl}_{2} / \mathrm{THF}$ $0^{\circ} \mathrm{C} \rightarrow \mathrm{rt}$

for 4: propargyl bromide

$\mathrm{DBU}$, toluene, $90^{\circ} \mathrm{C}$

for 5-6: hydroxamic acid,

(i) isocyanate, $\mathrm{CuCl}$,

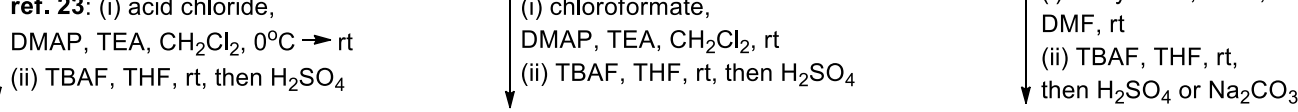

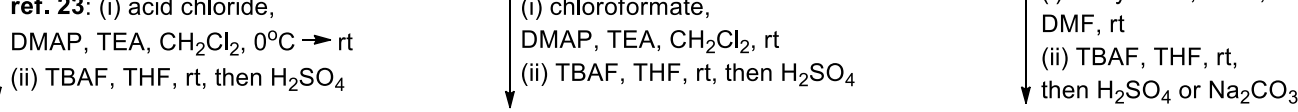
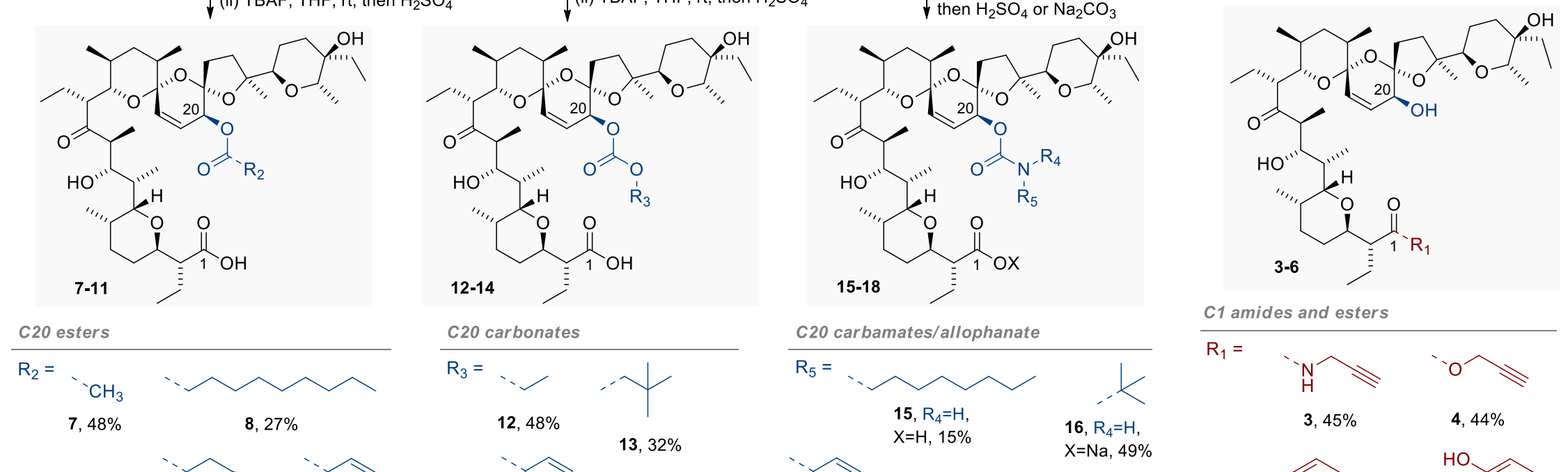

C1 amides and esters
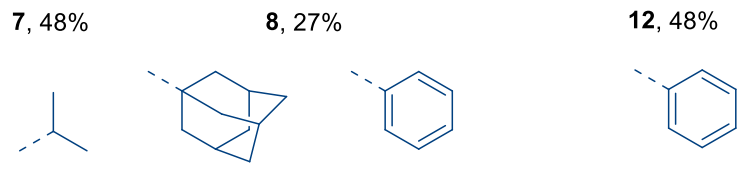

$13,32 \%$

14, $10 \%$
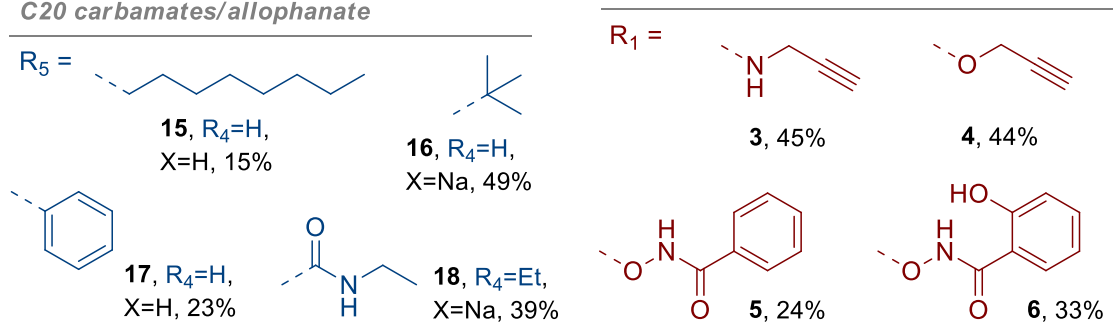

Scheme 1. Synthesis of single modified analogues of C20-epi-salinomycin. 
Having access to the key intermediate 1, numerous C20-O-acylated analogues of $\mathbf{2}$ were also obtained (Scheme 1). Firstly, the acylation of $\mathbf{1}$ with respective acid chlorides in the presence of TEA and excess of DMAP afforded the corresponding C20-epi-ester derivatives 7-11 in moderate yields (Scheme 1). This group included the literature-known esters 7 and 11 [23] and three other derivatives $(\mathbf{8}-\mathbf{1 0})$ that were synthesized for the first time which differed in length and arrangement (branching) of the aliphatic substituents. In all cases, the TMSEt masking group could be cleanly cleaved with TBAF [24], and the products were isolated in acid form after washing with aqueous solution of $\mathrm{H}_{2} \mathrm{SO}_{4}$. Moreover, to widen the structural diversity at the $\mathrm{C} 20$ position and to facilitate structure-activity relationship (SAR) studies, we also devised and obtained a completely new series of C20-epi-carbonates and C20-epi-carbamates (Scheme 1). While C20-epi-carbonates 12-14 were readily obtained from the reactions with a variety of chloroformates, C20carbamoylated products $\mathbf{1 5}-\mathbf{1 7}$ were formed exclusively in reactions with respective isocyanates that required addition of catalytic amounts of $\mathrm{CuCl}$ (Scheme 1). Of note is that under the same reaction conditions, treatment of $\mathbf{1}$ with ethyl isocyanate and $\mathrm{CuCl}$ gave the corresponding allophanate 18 (Scheme 1) as the main product. After deprotection with TBAF [24] and further extraction with aqueous solution of $\mathrm{H}_{2} \mathrm{SO}_{4}, \mathrm{C} 20$ carbonates and two $\mathrm{C} 20$ carbamates of 2 (compound 15 and 17) were obtained in acid form with the overall yield of 10-48\%. However, as carbamate $\mathbf{1 6}$ and allophanate $\mathbf{1 8}$ were found to undergo decomposition upon acidic extraction, we decided to isolate these products exclusively in the sodium salt form, which was accomplished by washing them with aqueous solution of $\mathrm{Na}_{2} \mathrm{CO}_{3}$.

Finally, as a continuation of our studies into the synthesis of multiple-modified SAL derivatives with improved activity profiles, we also synthesized a completely new series of C1/C20 double modified derivatives of $\mathbf{2}$ (Scheme 2). According to the procedures for the single modified 
analogues (Scheme 1), the $\mathrm{C} 1$ carboxyl group of two selected $\mathrm{C} 20$-epi-O-acylated derivatives, i.e. C20 acetate $\mathbf{7}$ and C20 ethyl carbonate 12, was transformed to the respective amide and ester derivatives 19-22 (C20 ester moiety) and 23-24 (C20 carbonate moiety) in moderate to good yields (17-57\%) (Scheme 2).

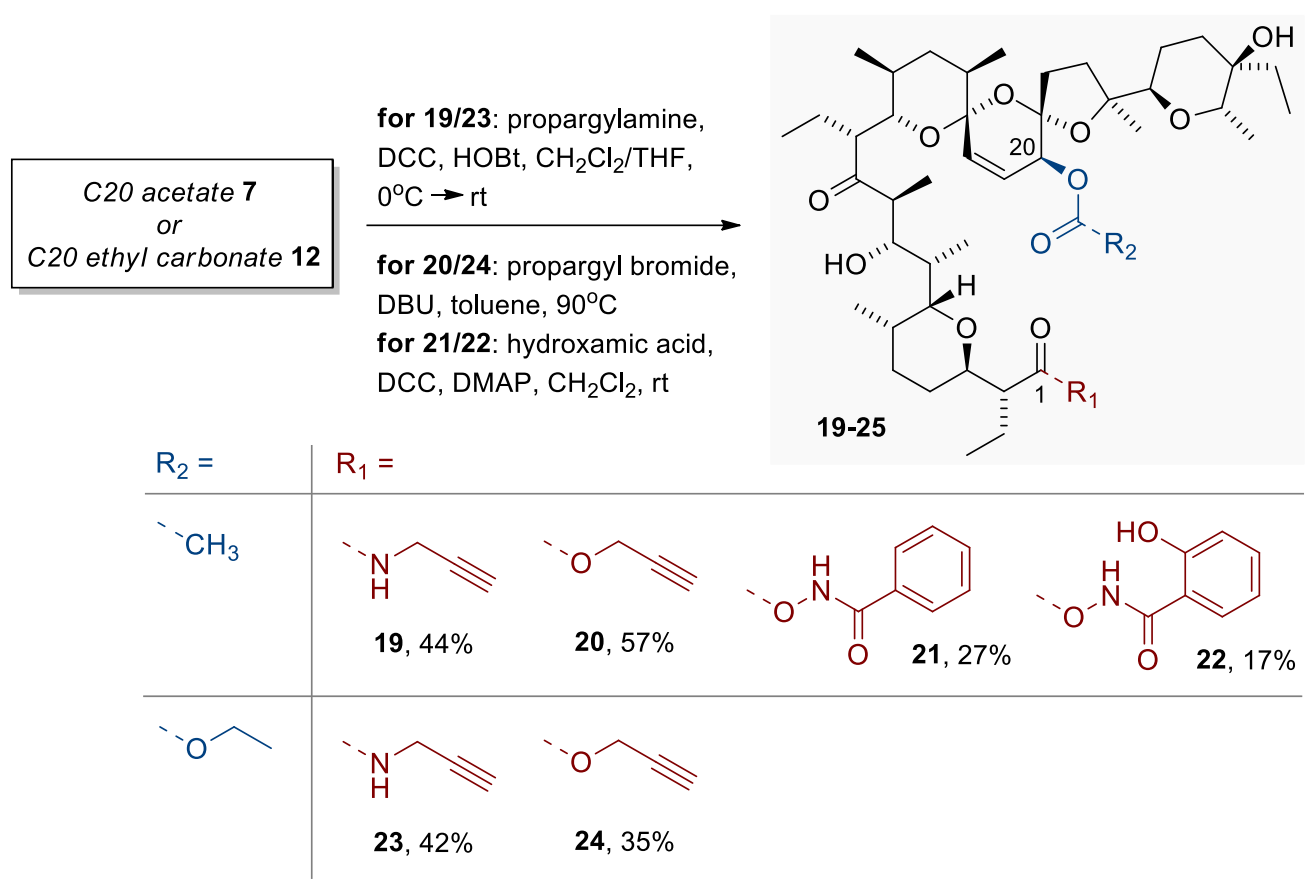

Scheme 2. Synthesis of double modified analogues of C20-epi-salinomycin.

Purity and structure of the newly obtained analogues of SAL were determined based on spectroscopic (FT-IR, NMR) data as well as on spectrometric (ESI MS) data. The NMR and ESI MS spectra of all novel analogues of $\mathbf{2}$ can be found in the Supplementary material (Figures S1S63). The positions of the C20-O-acyl groups in the structures of each derivative could be unequivocally assigned to a diagnostic downfield shift of the allylic protons relative to the position of the corresponding signal for $\mathbf{2}$. The structure of allophanate $\mathbf{1 8}$ was determined on the basis of ${ }^{1} \mathrm{H}$ and ${ }^{13} \mathrm{C}$ NMR spectra (Supplementary material, Figures S40-41), together with respective 2D 
NMR spectra, i.e. ${ }^{1} \mathrm{H}_{-}{ }^{13} \mathrm{C}$ HETCOR, ${ }^{1} \mathrm{H}_{-}{ }^{13} \mathrm{C}$ HMBC and ${ }^{1} \mathrm{H}-{ }^{1} \mathrm{H} \mathrm{COSY}$ (Supplementary material, Figures S43-S45).

Briefly, in the ${ }^{13} \mathrm{C}$ NMR spectra of $\mathrm{C} 1$ singly modified analogues, the analytical signals of amide and ester groups were observed at $174.6 \mathrm{ppm}$ (for propargyl amide $\mathbf{3}$ ) and in a narrow range of 173.4-174.8 ppm (for esters 4-6), respectively, while the signal of $\mathrm{C} 1$ carboxylate of $\mathbf{2}$ was found at $184.1 \mathrm{ppm}$. Further, in the ${ }^{1} \mathrm{H}$ NMR spectra, the signal of the highest analytical significance was that of the amide proton in $\mathbf{3}$, which appeared at $6.42 \mathrm{ppm}(\mathrm{t}, J=4.8 \mathrm{~Hz}, 1 \mathrm{H})$. With respect to C20-epi-O-acylated analogues, in the ${ }^{13} \mathrm{C}$ NMR spectra of the newly synthesized analogues 8-10, the most characteristic signals of the ester groups introduced at $\mathrm{C} 20$ position were observed in a narrow range of 172.8-176.5 ppm, while for C20-epi-carbonates 12-14, C20-epicarbamates 15-17 and allophanate 18, the corresponding $O$-acyl signals were found in the range of $153.1-154.9 \mathrm{ppm}, 152.7-156.0 \mathrm{ppm}$ and $155.8 \mathrm{ppm}$, respectively. For $\mathrm{C} 1 / \mathrm{C} 20$ doubly modified derivatives of $\mathbf{2}$, the positions of these characteristic signals were insignificantly shifted towards higher or lower ppm values.

\subsection{Trypanocidal activity}

SAL, C20-epi-salinomycin $\mathbf{2}$ and its derivatives 3-24 were assessed for their activity towards T. brucei bloodstream forms and HL-60 human myeloid cells in vitro, employing the resazurin cell viability test [26-27]. The trypanocidal and cytotoxic activity of the compounds were expressed as MIC values (minimum inhibitory concentration, which is the concentration of a compound that kills all cells; shown in Table $\mathrm{S} 1)$ and $\mathrm{GI}_{50}$ values (50\% growth inhibition value, which is the concentration of a compound needed to reduce the cell growth by $50 \%$ in comparison with controls; shown in Table 1). 
The first thing to mention is that C20-epi-salinomycin $\mathbf{2}$ is 10 times less trypanocidal with respect to $\mathrm{GI}_{50}$ and MIC values than SAL (Table 1 and Table S1). This finding is remarkable, given that the difference between $\mathbf{2}$ and $\mathbf{S A L}$ is just the stereoisomeric configuration of the C20 hydroxyl group. In contrast, no significant difference in cytotoxic activity against human HL-60 cells was found between the two epimers 2 and SAL. All synthesized derivatives (3-24) of 2 showed a concentration-dependent anti-proliferative effect on T. brucei bloodstream-form. With the exception of compounds $3,4,6,7,13,17,19,20,23$, and 24 , all other derivatives displayed higher anti-trypanosomal activity than the parent substance $\mathbf{2}$. The most trypanocidal compounds were 8, 12 and 18 with MIC values of $\leq 1 \mu \mathrm{M}$ and mid-nanomolar $\mathrm{GI}_{50}$ values. Importantly, these three derivatives showed similar anti-trypanosomal activity as suramin, a medication commonly used in sleeping sickness therapy. With respect to $\mathrm{GI}_{50}$ values, most derivatives showed similar or slightly increased cytotoxic activity towards human HL-60 cells than the parent compound $\mathbf{2}$. The most trypanocidal compounds $\mathbf{8}, \mathbf{1 2}$ and $\mathbf{1 8}$ were also the most cytotoxic compounds. The derivatives 4, 16, 19, and 24 displayed no cytotoxic action against human HL-60 cells (MIC and $\mathrm{GI}_{50}$ value $>100 \mu \mathrm{M}$ ). All derivatives (except 4, 16, 19, and 24) displayed the same MIC value of $100 \mu \mathrm{M}$ for HL-60 cells as compound 2.

For most derivatives, the selectivity indices (MIC and $\mathrm{GI}_{50}$ ratios of cytotoxicity to antitrypanosomal activity) were $\leq 100$ (Table 1 and Table S1). Only compounds 8, 12, 15, 16, and 18 had selectivity indices of $\geq 100$ and thus approached the MIC and $\mathrm{GI}_{50}$ ratios of suramin. Nevertheless, as suramin does not exhibit any toxicity towards human HL-60 cells, its selectivity still surpasses that of the most trypanocidal compounds.

SAR analysis did not reveal many conclusive correlations between the different chemical modifications and trypanocidal activity. For example, the modification pattern of the three most 
trypanocidal derivatives $\mathbf{8}, \mathbf{1 2}$ and $\mathbf{1 8}$ did not have anything in common. However, it was found that $\mathrm{C} 1$ propargyl esters $(\mathbf{4}, \mathbf{2 0}$, and $\mathbf{2 4})$ and $\mathrm{C} 1$ propargyl amides $(\mathbf{3}, \mathbf{1 9}$, and $\mathbf{2 3})$ displayed lower trypanocidal activity than the unmodified compound 2 . Moreover, additional modification of the C20 hydroxyl group $(\mathbf{1 9}, \mathbf{2 0}, \mathbf{2 3}$, and $\mathbf{2 4}$ ) had little effect on the trypanocidal action indicating that propargyl esterification and amidation of $\mathrm{C} 1$ was responsible for the loss of activity. For instance, C1 propargyl ester or amide modification of compound $\mathbf{1 2}$, one of the three most trypanocidal derivatives, led to a nearly 100-fold reduction of anti-trypanosomal activity of the resulting compounds 19 and 20. Likewise, a reduction in trypanocidal activity after introduction of the propargyl moiety at the C1 position were previously obtained with $\mathbf{S A L}$ and its C20-oxo analogue $[9,18]$. On the other hand, $\mathrm{C} 1$ benzhydroxamic acid esters (5 and 21) and C1 salicylhydroxamic acid esters (6 and 22) showed increased trypanocidal activity. Again, similar observations were previously made with $\mathrm{C} 1$ benzhydroxamic and C1 salicylhydroxamic acid esters of SAL and C20oxosalinomycin [18]. Modification of the C20 hydroxyl group with a long aliphatic chain (C20 deconate $\mathbf{8}$ and C20 octyl carbamate 15) resulted in derivatives with increased trypanocidal activity. Whether the increased anti-trypanosomal activity was due to increased lipophilicity brought by the aliphatic chain, remains to be shown. 
Table 1. GI $_{50}$ values and ratios of salinomycin (SAL), C20-epi-salinomycin (2) and its analogues (3-24) for T. brucei and HL-60 cells.

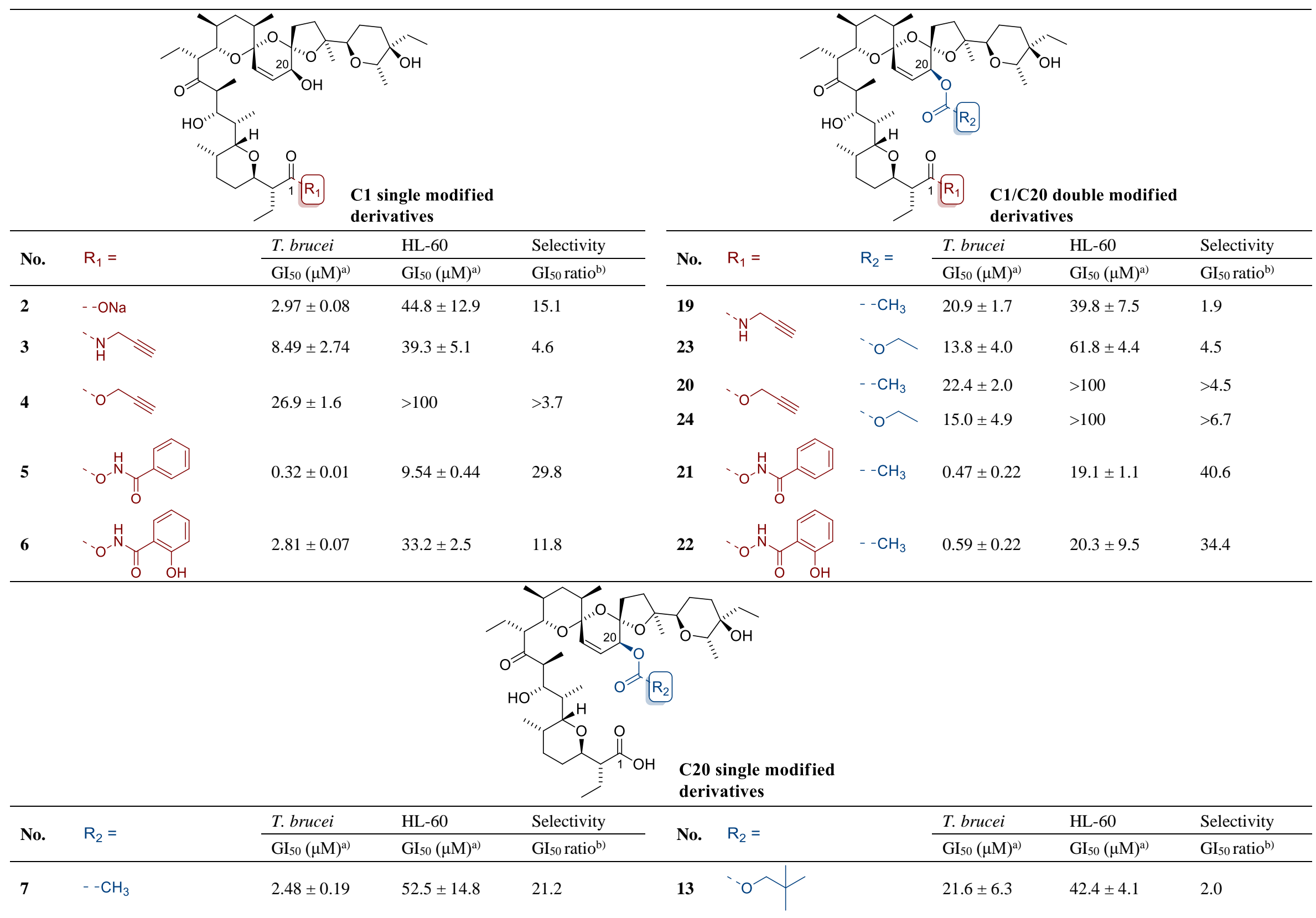




\begin{tabular}{|c|c|c|c|c|c|c|c|}
\hline 8 & $0.036 \pm 0.007$ & $5.97 \pm 0.40$ & 165 & 14 & $0.22 \pm 0.03$ & $23.4 \pm 4.1$ & 106 \\
\hline 9 & $0.24 \pm 0.04$ & $21.6 \pm 2.1$ & 90.0 & 15 & $0.20 \pm 0.03$ & $24.6 \pm 3.4$ & 123 \\
\hline 10 & $0.34 \pm 0.05$ & $18.7 \pm 6.3$ & 55.0 & $16^{c)}$ & $0.32 \pm 0.04$ & $>100$ & $>312$ \\
\hline 11 & $0.20 \pm 0.06$ & $13.5 \pm 1.7$ & 67.5 & 17 & $3.15 \pm 0.16$ & $57.2 \pm 7.0$ & 18.2 \\
\hline 12 & $0.043 \pm 0.010$ & $12.6 \pm 0.4$ & 293 & $18^{\mathrm{c})}$ & $0.027 \pm 0.002$ & $9.54 \pm 0.6$ & 353 \\
\hline
\end{tabular}

Reference controls

\begin{tabular}{|c|c|c|c|c|c|c|c|}
\hline \multirow{2}{*}{ No. } & T. brucei & HL-60 & Selectivity & \multirow{2}{*}{ No. } & T. brucei & HL-60 & Selectivity \\
\hline & $\mathrm{GI}_{50}(\mu \mathrm{M})^{\mathrm{a})}$ & $\mathrm{GI}_{50}(\mu \mathrm{M})^{\mathrm{a})}$ & $\mathrm{GI}_{50}$ ratio $^{\mathrm{b})}$ & & $\mathrm{GI}_{50}(\mu \mathrm{M})^{\mathrm{a})}$ & $\mathrm{GI}_{50}(\mu \mathrm{M})^{\mathrm{a})}$ & GI $_{50}$ ratio $^{\text {b) }}$ \\
\hline SAL & $0.30 \pm 0.08$ & $50.5 \pm 3.9$ & 168 & Suramin & $0.058 \pm 0.026$ & $>100$ & $>1724$ \\
\hline
\end{tabular}

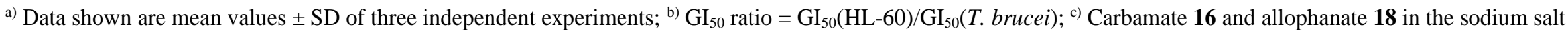
form. 
Of note is that SAL derivatives that have been identified as potent trypanocidal agents, generally also showed increased ionophoretic activity $[9,18]$. To see, whether the reduced and increased anti-trypanosomal activity of C20-epi-salinomycin $\mathbf{2}$ and of the most trypanocidal derivatives $\mathbf{8}, \mathbf{1 2}$, and $\mathbf{1 8}$, respectively, was linked to their ionophoretic activity, swelling experiments were performed. Upon exposure to ionophoretic active compounds, the cell volume of bloodstream form trypanosomes usually increases, which can be determined by light scattering measurements $[9,18,26]$. In contrast to $\mathbf{S A L}, \mathbf{C} 20$-epi-salinomycin $\mathbf{2}$ did not induce significant swelling in trypanosomes (Figure 1). This result is in agreement with the finding that $\mathbf{2}$ was about 10-times less trypanocidal than SAL (Table 1 and Table S1) and with previous observations that compounds with MIC values of $\geq 10 \mu \mathrm{M}$ and $\mathrm{GI}_{50}$ values of $\geq 3 \mu \mathrm{M}$ display much lower ionophoretic activity [9]. Compared to SAL, the derivatives 8, 12, and $\mathbf{1 8}$ produced slightly enhanced swelling in trypanosomes. This result confirms previous findings that compounds with lower MIC and GI $_{50}$ values than SAL generally display increased ionophoretic activity $[9,18]$.

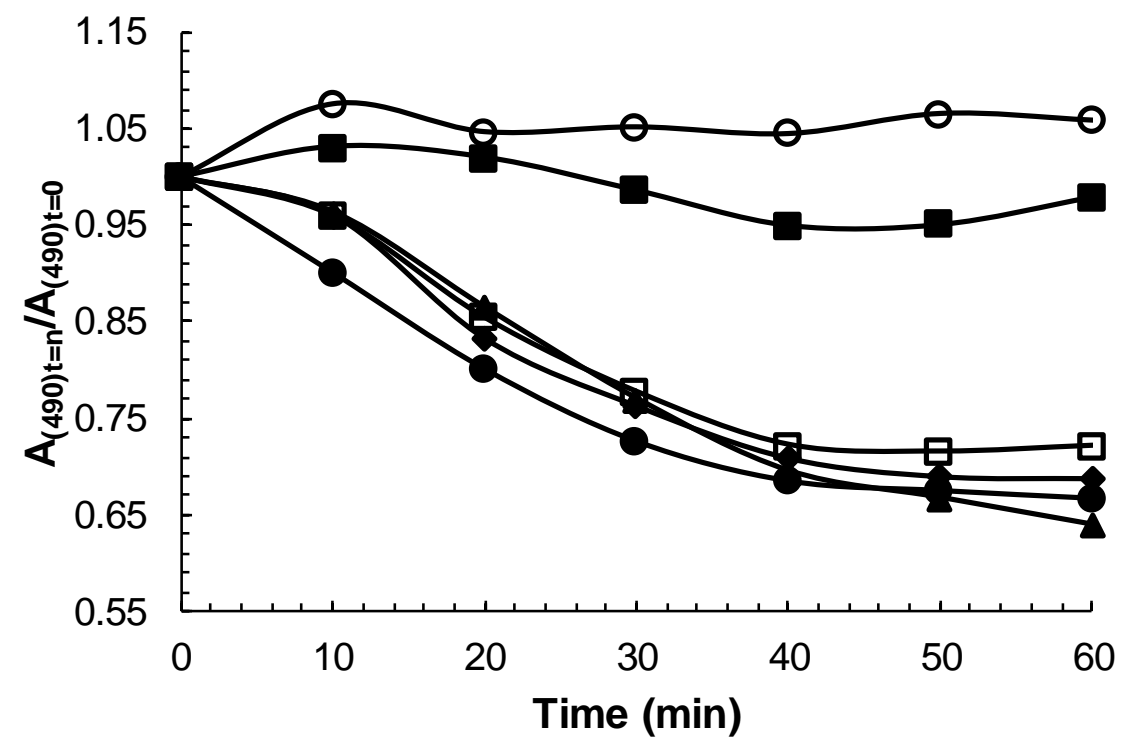

Figure 1. Effect of C20-epi-salinomycin analogues on cell swelling of bloodstream forms of T. brucei. Trypanosomes $\left(5 \times 10^{7} \mathrm{~mL}^{-1}\right)$ were exposed to $100 \mu \mathrm{M}$ ionophoretic active compounds in Baltz medium in the presence of $0.9 \%$ 
DMSO. The absorbance at $490 \mathrm{~nm}$ of the culture was measured every $10 \mathrm{~min}$. Open circles, DMSO control; open squares, SAL (salinomycin); closed squares, 2 (C20-epi-salinomycin); closed triangles, 8 (C20 decanoate of C20-episalinomycin); closed diamonds, 12 (C20 ethyl carbonate of C20-epi-salinomycin); closed circles, 18 (C20 allophanate of C20-epi-salinomycin). An increase in absorbance is reflected by a decrease in absorbance. For reasons of simplicity, only average values of three independent experiments are shown. The standard deviations varied between 1.1 and 11.4 percentage points.

\section{Conclusions}

Taken together, a series of analogues of C20-epi-salinomycin (2) was synthesized. It included products obtained by chemical modification at either $\mathrm{C} 1$ or $\mathrm{C} 20$ position of $\mathbf{2}$, but also C1/C20 doubly modified derivatives. All derivatives were assessed for their anti-trypanosomal activity and selectivity using in vitro experiments. More than half of the compounds showed higher activity towards $T$. brucei than the parent substance 2 , but only three $(\mathbf{8}, \mathbf{1 2}$, and 18) displayed enhanced anti-trypanosomal action compared with SAL. However, six analogues $(\mathbf{8}, 12,14,15$, 16, and 18) meet the activity criteria for hit compounds for T. brucei, which are $\mathrm{GI}_{50}<1 \mu \mathrm{M}$ and selectivity $>100$ [28]. Interestingly, all six compounds were C20 single modified derivatives indicating that modification at the $\mathrm{C} 20$ position may be the rationale for future drug candidate development.

\section{Experimental}

\subsection{General procedures}

All commercially available reagents and solvents were purchased from two independent sources (Merck (Germany) or Trimen Chemicals S.A. (Poland)) and used in the experiments without further purification. Detailed description of general procedures, used equipment (NMR 
spectrometer, FT-IR spectrophotometer, mass spectrometer), measurement parameters and software can be found either in the Supplementary material or in the reference literature [18-19]. The ${ }^{1} \mathrm{H}$ and ${ }^{13} \mathrm{C}$ NMR signals of allophanate 18 were assigned using the gradient-enhanced version of the 2D experiments $\left({ }^{1} \mathrm{H}-{ }^{13} \mathrm{C}\right.$ HETCOR, ${ }^{1} \mathrm{H}-{ }^{13} \mathrm{C}$ HMBC and ${ }^{1} \mathrm{H}-{ }^{1} \mathrm{H}$ COSY $)$ shown in the Supplementary material (Figures S43-S45). The 2D spectra were recorded using standard pulse sequences from Bruker pulse-sequence libraries.

\subsection{Synthesis}

SAL in its sodium salt form was isolated in gram quantities from commercially available veterinary premix $\mathrm{SACOX}^{\circledR}$, according to previous protocols [21-22]. To obtain the free acid form of SAL, the isolated ionophore in its sodium salt form was dissolved in $\mathrm{CH}_{2} \mathrm{Cl}_{2}$ and extracted 2-3 times with aqueous sulphuric acid $(\mathrm{pH}=1.0)$ by vigorously mixing the organic and aqueous layers. The collected organic layers containing SAL were thoroughly washed once with water, and then evaporated in vacuo giving sodium-free SAL as a clear oil. The oil was easily transformed into a white amorphous solid after thrice evaporation with $n$-pentane to dryness. The spectroscopic data of SAL were in line with previously published data [29].

C20-epi-salinomycin 2, together with its two C20 ester derivatives (compound $\mathbf{7}$ and $\mathbf{1 1}$, Scheme 1) were re-synthesized following the protocol published by $\mathrm{Wu}$ and co-workers [23]. The NMR data of $\mathbf{2}$ as well as its analogues $\mathbf{7}$ and $\mathbf{1 1}$ were in line with those found in the reference literature.

\subsubsection{Synthesis of C1 propargyl amide of C20-epi-salinomycin (analogue 3)}


Initially, the sodium salt of $\mathrm{C} 20$-epi-salinomycin 2 was dissolved in $\mathrm{CH}_{2} \mathrm{Cl}_{2}$ and quantitatively transformed into its free acid form by twice extraction with sulphuric acid $(\mathrm{pH}=$ 1.0) and subsequent washing of the combined organic layers with water, and evaporation of the organic solvent in vacuo. Then, to a stirred solution of 2 (100 $\mathrm{mg}, 0.13 \mathrm{mmol}, 1.0$ equiv.) in anhydrous $\mathrm{CH}_{2} \mathrm{Cl}_{2}(10 \mathrm{~mL})$ at $0{ }^{\circ} \mathrm{C}$, the following reagents were added: DCC $(32 \mathrm{mg}, 0.16 \mathrm{mmol}$, 1.2 equiv.), HOBt (10 mg, $0.07 \mathrm{mmol}, 0.5$ equiv., dissolved in $3 \mathrm{~mL}$ of anhydrous THF) and propargylamine (18 $\mathrm{mg}, 0.33 \mathrm{mmol}, 2.5$ equiv.). The temperature of the reaction mixture was raised to room temperature, and stirring was continued for $48 \mathrm{~h}$. Then, the mixture was concentrated in vacuo and purified chromatographically on silica gel using the CombiFlash system $(0 \rightarrow 50 \%$ EtOAc/n-hexane) to give the pure product 3 (45\% yield) as a clear oil. After thrice evaporation to dryness with $n$-pentane, the oily product was completely converted into a white amorphous solid. The ${ }^{1} \mathrm{H}$ and ${ }^{13} \mathrm{C}$ NMR spectra of the amide 3 can be found in the Supplementary material (Figures S1-S2).

Yield: $47 \mathrm{mg}, 45 \%$. Isolated as a white amorphous solid, >95\% pure by NMR and a single spot by TLC. Strains green with PMA; ${ }^{1} \mathrm{H}$ NMR $\left(401 \mathrm{MHz}, \mathrm{CDCl}_{3}\right) \delta 6.42(\mathrm{t}, J=5.5 \mathrm{~Hz}, 1 \mathrm{H})$, $5.89(\mathrm{dd}, J=10.1,1.6 \mathrm{~Hz}, 1 \mathrm{H}), 5.42(\mathrm{dd}, J=10.1,2.3 \mathrm{~Hz}, 1 \mathrm{H}), 4.36(\mathrm{ddd}, J=17.8,5.9,2.3 \mathrm{~Hz}$, 1H), 4.17-4.13 (m, 2H), 4.11-4.06 (m, 2H), $3.95(\mathrm{dd}, J=10.0,5.1 \mathrm{~Hz}, 1 \mathrm{H}), 3.85(\mathrm{~d}, J=8.4 \mathrm{~Hz}$, 2H), 3.83-3.79 (m, 1H), $3.68(\mathrm{dd}, J=15.1,6.8 \mathrm{~Hz}, 2 \mathrm{H}), 3.12(\mathrm{~d}, J=5.0 \mathrm{~Hz}, 1 \mathrm{H}), 2.97(\mathrm{dt}, J=$ 14.5, 7.4 Hz, 1H), 2.35-2.24 (m, 4H), $2.14(\mathrm{t}, J=2.5 \mathrm{~Hz}, 1 \mathrm{H}), 2.00-0.50(\mathrm{~m}, 52 \mathrm{H}) \mathrm{ppm} ;{ }^{13} \mathrm{C}$ NMR $\left(101 \mathrm{MHz}, \mathrm{CDCl}_{3}\right) \delta 215.9,174.6,131.0,128.9,109.7,99.9,86.6,80.8,77.6,75.2,74.1,71.2$, $70.8,70.6,69.9,69.2,57.2,49.2,48.6,38.9,38.6,36.1,36.0,33.2,31.1,30.8,30.5,29.1,28.9$, $28.2,26.4,25.9,22.6,22.2,21.3,20.3,18.1,15.6,14.5,13.8,13.3,11.8,11.3,7.4,6.3$ ppm; FTIR (KBr tablet): 3447 (br, m), 3316 (m), 2968 (s), 2939 (s), 2877 (m), 2124 (w), 1720 (m), 1659 
(w), $1533(\mathrm{~m}), 1454(\mathrm{~m}), 1387(\mathrm{~m}) \mathrm{cm}^{-1}$; ESI MS (m/z): [M+Na $]^{+}$Calcd for $\mathrm{C}_{45} \mathrm{H}_{73} \mathrm{NNaO}_{10}{ }^{+} 810.5$; Found 811.

\subsubsection{Synthesis of C1 propargyl ester of C20-epi-salinomycin (analogue 4)}

To a solution of sodium-free 2 (prepare as described above; $100 \mathrm{mg}, 0.13 \mathrm{mmol}, 1.0$ equiv.) in anhydrous toluene (10 mL), DBU (24 mg, $0.16 \mathrm{mmol}, 1.2$ equiv.) and propargyl bromide ( $80 \%$ in toluene; $46 \mathrm{mg}, 0.39 \mathrm{mmol}, 3.0$ equiv.) were added under stirring and the solution was heated at $90{ }^{\circ} \mathrm{C}$ for $6 \mathrm{~h}$. The solution was then concentrated in vacuo. Purification on silica gel using the CombiFlash system $(0 \rightarrow 30 \%$ EtOAc/ $n$-hexane) gave the pure product 4 (44\% yield) as a clear oil. After thrice evaporation to dryness with $n$-pentane, the oily product was completely converted into a white amorphous solid. The ${ }^{1} \mathrm{H}$ and ${ }^{13} \mathrm{C}$ NMR spectra of ester 4 can be found in the Supplementary material (Figures S4-S5).

Yield: $46 \mathrm{mg}, 44 \%$. Isolated as a white amorphous solid, $>95 \%$ pure by NMR and a single spot by TLC. Strains green with PMA; ${ }^{1} \mathrm{H}$ NMR (401 MHz, $\left.\mathrm{CDCl}_{3}\right) \delta 5.84(\mathrm{dd}, J=10.1,1.6 \mathrm{~Hz}$, 1H), $5.41(\mathrm{dd}, J=10.1,2.5 \mathrm{~Hz}, 1 \mathrm{H}), 5.04(\mathrm{dd}, J=15.8,2.4 \mathrm{~Hz}, 1 \mathrm{H}), 4.84(\mathrm{dd}, J=15.8,2.5 \mathrm{~Hz}$ $1 \mathrm{H}), 4.16-4.14(\mathrm{~m}, 1 \mathrm{H}), 4.06(\mathrm{dd}, J=11.0,5.8 \mathrm{~Hz}, 1 \mathrm{H}), 3.96(\mathrm{dd}, J=9.1,5.4 \mathrm{~Hz}, 1 \mathrm{H}), 3.90(\mathrm{~d}, J$ $=1.1 \mathrm{~Hz}, 1 \mathrm{H}), 3.87-3.78(\mathrm{~m}, 2 \mathrm{H}), 3.71(\mathrm{dd}, J=10.8,3.3 \mathrm{~Hz}, 1 \mathrm{H}), 3.62(\mathrm{dd}, J=9.8,1.6 \mathrm{~Hz}, 1 \mathrm{H})$, $3.11-2.98(\mathrm{~m}, 2 \mathrm{H}), 2.74(\mathrm{~d}, J=5.5 \mathrm{~Hz}, 1 \mathrm{H}), 2.69(\mathrm{ddd}, J=8.8,4.8,1.7 \mathrm{~Hz}, 1 \mathrm{H}), 2.46(\mathrm{t}, J=2.4$ $\mathrm{Hz}, 1 \mathrm{H}), 2.42(\mathrm{~s}, 1 \mathrm{H}), 2.39-2.33(\mathrm{~m}, 1 \mathrm{H}), 2.32-2.26(\mathrm{~m}, 1 \mathrm{H}), 2.26-2.19(\mathrm{~m}, 2 \mathrm{H}), 2.00-0.50$ (m, 50H) ppm; ${ }^{13} \mathrm{C}$ NMR (101 MHz, $\left.\mathrm{CDCl}_{3}\right) \delta 215.0,174.8,130.5,129.2,109.7,99.9,86.5,78.2$, $77.3,76.8,74.80,74.75,74.1,71.7,70.8,69.5,69.3,56.6,52.6,48.4,48.2,38.8,36.3,35.9,33.2$, $30.9,30.7,30.5,29.2,28.0,26.2,25.9,22.7,22.2,20.9,19.6,18.1,15.7,14.5,13.8,13.3,11.7$, 10.8, 7.2, 6.3 ppm; FT-IR (KBr tablet): 3550 (br, m), 3438 (m), 3311 (m), 2965 (s), 2939 (s), 2877 
(m), $2124(\mathrm{w}), 1723(\mathrm{~s}), 1624(\mathrm{w}), 1460(\mathrm{~m}), 1387(\mathrm{~m}) \mathrm{cm}^{-1}$; ESI MS (m/z): [M+Na] $]^{+}$Calcd for $\mathrm{C}_{45} \mathrm{H}_{72} \mathrm{NaO}_{11}{ }^{+}$811.5; Found 811.9.

4.2.3. General procedure for preparation of C1 esters of C20-epi-salinomycin with hydroxamic acids (analogues 5 and 6 )

To a solution of sodium-free 2 (prepared as described above; 1.0 equiv.) in anhydrous $\mathrm{CH}_{2} \mathrm{Cl}_{2}$, DCC (2.0 equiv.) and DMAP (2.0 equiv.) were introduced under stirring at ambient temperature. Then, the respective hydroxamic acid (5.0 equiv.) was added in one portion. The resulting solutions were stirred for $48 \mathrm{~h}$, and subsequently diluted with $\mathrm{CH}_{2} \mathrm{Cl}_{2}$ and washed with saturated $\mathrm{NH}_{4} \mathrm{Cl}$. The organic phases of the reaction mixtures were separated and concentrated in vacuo to give clear oils. Purification on silica gel using the CombiFlash system $(0 \rightarrow 50 \%$ EtOAc/nhexane) gave the pure products 5 and $\mathbf{6}$ (24-33\% yield) as clear oils. After thrice evaporation to dryness with $n$-pentane, the oily products were completely converted into white amorphous solids. The ${ }^{1} \mathrm{H}$ and ${ }^{13} \mathrm{C}$ NMR spectra of esters 5 and $\mathbf{6}$ can be found in the Supplementary material (Figures S7-S8 and Figures S10-S11, respectively).

Cl benzhydroxamic acid ester of C20-epi-salinomycin 5: Yield: $28 \mathrm{mg}, 24 \%$. Isolated as a white amorphous solid, >95\% pure by NMR and a single spot by TLC. UV-active and strains green with PMA; ${ }^{1} \mathrm{H}$ NMR (401 MHz, $\left.\mathrm{CDCl}_{3}\right) \delta 11.09$ (s, $\left.1 \mathrm{H}\right), 8.12(\mathrm{dd}, J=8.4,1.3 \mathrm{~Hz}, 2 \mathrm{H}), 7.47-7.40$ $(\mathrm{m}, 1 \mathrm{H}), 7.34(\mathrm{dd}, J=10.4,4.7 \mathrm{~Hz}, 2 \mathrm{H}), 6.22(\mathrm{~d}, J=10.6 \mathrm{~Hz}, 1 \mathrm{H}), 6.17-6.11(\mathrm{~m}, 1 \mathrm{H}), 4.07(\mathrm{dd}, J$ $=11.0,6.2 \mathrm{~Hz}, 1 \mathrm{H}), 4.01(\mathrm{t}, J=6.5 \mathrm{~Hz}, 1 \mathrm{H}), 3.79(\mathrm{~d}, J=3.5 \mathrm{~Hz}, 1 \mathrm{H}), 3.75-3.69(\mathrm{~m}, 1 \mathrm{H}), 3.67(\mathrm{~d}$, $J=10.1 \mathrm{~Hz}, 2 \mathrm{H}), 3.41(\mathrm{dd}, J=11.9,2.2 \mathrm{~Hz}, 1 \mathrm{H}), 3.12(\mathrm{td}, J=11.0,3.7 \mathrm{~Hz}, 1 \mathrm{H}), 2.92-2.83(\mathrm{~m}$, $1 \mathrm{H}), 2.50(\mathrm{~d}, J=9.6 \mathrm{~Hz}, 1 \mathrm{H}), 2.12(\mathrm{ddd}, J=12.5,11.5,8.9 \mathrm{~Hz}, 1 \mathrm{H}), 2.00-0.50(\mathrm{~m}, 56 \mathrm{H}) \mathrm{ppm} ;{ }^{13} \mathrm{C}$ NMR $\left(101 \mathrm{MHz}, \mathrm{CDCl}_{3}\right) \delta 215.5,173.4,165.4,131.9,131.1,130.6,128.2,128.1,124.4,108.9$, 
$98.5,89.3,79.8,74.6,73.4,72.0,70.9,68.4,66.0,54.0,46.7,46.3,39.3,38.3,36.3,33.9,32.4$, $31.0,30.6,29.4,28.1,26.5,25.8,25.6,24.9,23.2,21.8,19.8,17.1,16.5,14.4,14.3,14.2,11.8$, 10.9, 7.6, 6.5 ppm; FT-IR (KBr tablet): 3482 (br, m), 3307 (br, m), 2968 (s), 2930 (s), 2875 (m), 1790 (s), 1726 (s), 1697 (s), 1604 (w), 1579 (w), 1504 (w), 1463 (s), 1378 (m) cm c $^{-1}$ ESI MS (m/z): $[\mathrm{M}+\mathrm{Na}]^{+}$Calcd for $\mathrm{C}_{49} \mathrm{H}_{75} \mathrm{NNaO}_{12}{ }^{+}$892.5; Found 893 .

C1 salicylhydroxamic acid ester of C20-epi-salinomycin 6: Yield: $39 \mathrm{mg}, 33 \%$. Isolated as a white amorphous solid, $>95 \%$ pure by NMR and a single spot by TLC. UV-active and strains green with PMA; ${ }^{1} \mathrm{H}$ NMR $\left(401 \mathrm{MHz}, \mathrm{CDCl}_{3}\right) \delta 11.55(\mathrm{~s}, 1 \mathrm{H}), 11.32(\mathrm{~s}, 1 \mathrm{H}), 8.17(\mathrm{dd}, J=8.0$, $1.4 \mathrm{~Hz}, 1 \mathrm{H}), 7.40$ (ddd, $J=8.6,7.2,1.6 \mathrm{~Hz}, 1 \mathrm{H}), 6.97(\mathrm{dd}, J=8.4,1.0 \mathrm{~Hz}, 1 \mathrm{H}), 6.87-6.81(\mathrm{~m}$, 1H), $5.80(\mathrm{dd}, J=10.1,2.2 \mathrm{~Hz}, 1 \mathrm{H}), 5.41(\mathrm{dd}, J=10.1,2.1 \mathrm{~Hz}, 1 \mathrm{H}), 4.18(\mathrm{dd}, J=10.4,5.0 \mathrm{~Hz}$, 2H), $4.05(\mathrm{~s}, 1 \mathrm{H}), 3.86(\mathrm{~d}, J=11.4 \mathrm{~Hz}, 1 \mathrm{H}), 3.82(\mathrm{q}, J=6.9 \mathrm{~Hz}, 1 \mathrm{H}), 3.73(\mathrm{dd}, J=10.6,1.6 \mathrm{~Hz}$, $1 \mathrm{H}), 3.63(\mathrm{~d}, J=11.3 \mathrm{~Hz}, 2 \mathrm{H}), 3.22(\mathrm{td}, J=10.9,3.8 \mathrm{~Hz}, 1 \mathrm{H}), 3.06(\mathrm{dt}, J=14.8,7.4 \mathrm{~Hz}, 1 \mathrm{H})$, 2.84-2.78 (m, 1H), $2.44(\mathrm{~d}, J=5.1 \mathrm{~Hz}, 1 \mathrm{H}), 2.32-2.29(\mathrm{~m}, 1 \mathrm{H}), 2.22-2.17(\mathrm{~m}, 3 \mathrm{H}), 2.30-0.50(\mathrm{~m}$, 51H) ppm; ${ }^{13} \mathrm{C}$ NMR (101 MHz, $\left.\mathrm{CDCl}_{3}\right) \delta 218.4,173.5,168.8,161.4,134.6,131.0,129.5,127.5$, $118.7,118.0,111.9,109.7,99.5,86.5,74.5,73.9,72.0,70.8,69.0,68.6,56.4,49.3,47.1,38.8$ $35.9,35.7,33.9,32.7,31.4,31.2,30.5,29.1,27.9,26.4,25.5,24.9,23.1,22.1,20.7,19.9,17.9$, 15.6, 14.5, 13.5, 13.2, 11.6, 11.0, 7.1, 6.3 ppm; FT-IR (KBr tablet): 3450 (br, m), 3327 (br, m), 2968 (s), 2933 (s), 2877 (m), 1793 (m), 1764 (m), 1700 (m), 1653 (m), 1627 (m), 1609 (m), 1586 (m), $1513(\mathrm{~m}), 1467(\mathrm{~m}), 1373(\mathrm{~m}) \mathrm{cm}^{-1}$; ESI MS (m/z): [M+Na] $]^{+}$Calcd for $\mathrm{C}_{49} \mathrm{H}_{75} \mathrm{NNaO}_{13}{ }^{+}$908.5; Found 909. 
To a stirred solution of C20-epi-salinomycin intermediate $\mathbf{1}$ (1.0 equiv.) in anhydrous $\mathrm{CH}_{2} \mathrm{Cl}_{2}$ at $0{ }^{\circ} \mathrm{C}$, the following reagents were added: TEA (6.0 equiv.), an excess of DMAP, and the corresponding acyl chloride (3.0 equiv.) diluted in anhydrous $\mathrm{CH}_{2} \mathrm{Cl}_{2}$, which was added drop by drop over 30 seconds. The reaction mixtures were warmed to room temperature, stirred overnight, and then concentrated in vacuo. Purification on silica gel using the CombiFlash system $(0 \rightarrow 30 \%$ EtOAc/n-hexane) gave each intermediate ester product as a clear oil. In the next step, to a stirred solution of each intermediate product in THF at ambient temperature, TBAF (3.0 equiv., $1.0 \mathrm{M}$ in THF) was introduced dropwise over 30 seconds. The resulting slightly yellowish solutions were stirred until the starting materials were completely consumed (TLC control) and then concentrated in vacuo. Purification on silica gel using the CombiFlash system $(0 \rightarrow 50 \%$ EtOAc/n-hexane) provided the deprotected products as mixtures of their acid and salt forms. The product mixtures were dissolved again in $\mathrm{CH}_{2} \mathrm{Cl}_{2}$, washed with sulphuric acid $(\mathrm{pH}=1.0$ ), and extracted with water. The organic layers of the reaction mixtures were separated, and evaporated thrice from $n$-pentane to give the pure products 7-11 (17-48\% yield) as white amorphous solids. The ${ }^{1} \mathrm{H}$ and ${ }^{13} \mathrm{C}$ NMR spectra of the newly synthesized esters $\mathbf{8 , 9}$ and $\mathbf{1 0}$ can be found in the Supplementary material (Figures S13-S14, Figures S16-S17 and Figures S19-S20, respectively).

C20 decanoate of C20-epi-salinomycin 8: Yield: $70 \mathrm{mg}, 27 \%$. Isolated as a white amorphous solid, >95\% pure by NMR and a single spot by TLC. Strains green with PMA; ${ }^{1} \mathrm{H}$ NMR (401 MHz, CDCl $) \delta 6.34(\mathrm{~d}, J=10.6 \mathrm{~Hz}, 1 \mathrm{H}), 6.18(\mathrm{dd}, J=10.6,5.8 \mathrm{~Hz}, 1 \mathrm{H}), 4.94(\mathrm{~d}, J=$ $5.8 \mathrm{~Hz}, 1 \mathrm{H}), 4.12(\mathrm{~d}, J=10.0 \mathrm{~Hz}, 1 \mathrm{H}), 3.96(\mathrm{dd}, J=11.0,5.3 \mathrm{~Hz}, 1 \mathrm{H}), 3.89(\mathrm{~d}, J=10.3 \mathrm{~Hz}, 1 \mathrm{H})$, 3.84-3.75 (m, 1H), 3.66-3.58 (m, 3H), 2.92-2.83 (m, 1H), 2.78- $2.69(\mathrm{~m}, 1 \mathrm{H}), 2.58(\mathrm{dd}, J=11.7$, $9.7 \mathrm{~Hz}, 1 \mathrm{H}), 2.22(\mathrm{td}, J=7.4,2.7 \mathrm{~Hz}, 2 \mathrm{H}), 2.00-0.50(\mathrm{~m}, 72 \mathrm{H}) \mathrm{ppm} ;{ }^{13} \mathrm{C} \mathrm{NMR}\left(101 \mathrm{MHz}, \mathrm{CDCl}_{3}\right)$ $\delta 215.0,177.8,172.8,127.9,123.6,105.8,99.0,89.8,76.5,75.3,74.9,73.7,71.5,71.1,68.3,66.6$, 
$56.1,49.8,49.0,40.2,39.1,36.8,36.4,34.4,32.7,31.8,31.3,30.0,29.6,29.4,29.20,29.18,29.1$, $27.9,26.3,25.6,24.9,22.8,22.6,22.0,21.9,19.9,17.9,16.6,14.2,14.1,13.2,12.9,12.0,11.0$, 6.7, 6.4 ppm; FT-IR (KBr tablet): 3503 (br, m), 2959 (s), 2927 (s), 2880 (m), 1735 (s), 1714 (s), $1648(\mathrm{w}), 1460(\mathrm{~s}), 1381(\mathrm{~s}) \mathrm{cm}^{-1}$; ESI MS (m/z): [M+Na] $]^{+}$Calcd for $\mathrm{C}_{52} \mathrm{H}_{88} \mathrm{NaO}_{12}{ }^{+}$927.6; Found 928.

C20 isobutyrate of C20-epi-salinomycin 9: Yield: $79 \mathrm{mg}, 37 \%$. Isolated as a white amorphous solid, $>95 \%$ pure by NMR and a single spot by TLC. Strains green with PMA; ${ }^{1} \mathrm{H}$ NMR $\left(401 \mathrm{MHz}, \mathrm{CDCl}_{3}\right) \delta 6.34(\mathrm{~d}, J=10.6 \mathrm{~Hz}, 1 \mathrm{H}), 6.16(\mathrm{dd}, J=10.6,5.8 \mathrm{~Hz}, 1 \mathrm{H}), 4.95(\mathrm{~d}, J=$ $5.8 \mathrm{~Hz}, 1 \mathrm{H}), 4.12(\mathrm{dd}, J=10.2,1.5 \mathrm{~Hz}, 1 \mathrm{H}), 3.96(\mathrm{dd}, J=11.0,5.6 \mathrm{~Hz}, 1 \mathrm{H}), 3.89(\mathrm{~d}, J=10.3 \mathrm{~Hz}$ $1 \mathrm{H}), 3.80(\mathrm{~d}, J=6.9 \mathrm{~Hz}, 1 \mathrm{H}), 3.62(\mathrm{ddd}, J=9.9,7.3,2.8 \mathrm{~Hz}, 2 \mathrm{H}), 2.87(\mathrm{td}, J=10.9,3.7 \mathrm{~Hz}, 1 \mathrm{H})$, 2.77-2.71 (m, 1H), $2.60(\mathrm{dd}, J=11.0,2.5 \mathrm{~Hz}, 1 \mathrm{H}), 2.46(\mathrm{pd}, J=7.0,0.7 \mathrm{~Hz}, 1 \mathrm{H}), 2.05(\mathrm{dt}, J=$ 9.1, $2.3 \mathrm{~Hz}, 1 \mathrm{H}), 2.00-0.50(\mathrm{~m}, 61 \mathrm{H}) \mathrm{ppm} ;{ }^{13} \mathrm{C} \mathrm{NMR}\left(101 \mathrm{MHz}, \mathrm{CDCl}_{3}\right) \delta 215.1,177.8,175.9$, 127.9, 123.6, 105.8, 99.0, 89.83 76.5, 75.3, 74.9, 73.7, 71.5, 71.1, 68.3, 66.4, 56.1, 49.8, 49.0, 40.2, $39.1,36.8,36.4,34.1,32.7,31.2,30.1,29.6,27.9,26.3,25.7,22.8,22.0,19.8,18.9,18.7,17.9$, 16.6, 14.2, 13.2, 12.9, 12.0, 11.0, 6.7, 6.4 ppm; FT-IR (KBr tablet): 3503 (br, m), 2959 (s), 2880 (m), $1741(\mathrm{~m}), 1709(\mathrm{~m}), 1647(\mathrm{w}), 1460(\mathrm{~m}), 1387(\mathrm{~m}) \mathrm{cm}^{-1}$; ESI MS (m/z): [M+Na] $]^{+}$Calcd for $\mathrm{C}_{46} \mathrm{H}_{76} \mathrm{NaO}_{12}{ }^{+}$843.5; Found 844 .

C20-adamantane-1-carboxylate of C20-epi-salinomycin 10: Yield: $44 \mathrm{mg}, 17 \%$. Isolated as a white amorphous solid, $>95 \%$ pure by NMR and a single spot by TLC. Strains green with PMA; ${ }^{1} \mathrm{H}$ NMR (401 MHz, $\left.\mathrm{CDCl}_{3}\right) \delta 6.35(\mathrm{~d}, J=10.7 \mathrm{~Hz}, 1 \mathrm{H}), 6.14(\mathrm{dd}, J=10.6,5.8 \mathrm{~Hz}, 1 \mathrm{H})$, $4.96(\mathrm{~d}, J=5.9 \mathrm{~Hz}, 1 \mathrm{H}), 4.12(\mathrm{~d}, J=10.3 \mathrm{~Hz}, 1 \mathrm{H}), 3.96(\mathrm{dd}, J=10.8,5.0 \mathrm{~Hz}, 1 \mathrm{H}), 3.90(\mathrm{~d}, J=$ $10.2 \mathrm{~Hz}, 1 \mathrm{H}), 3.82-3.77(\mathrm{~m}, 1 \mathrm{H}), 3.67-3.60(\mathrm{~m}, 3 \mathrm{H}), 2.87$ (td, $J=10.9,3.9 \mathrm{~Hz}, 1 \mathrm{H}), 2.74(\mathrm{dd}, J=$ $10.2,7.1 \mathrm{~Hz}, 1 \mathrm{H}), 2.63-2.57(\mathrm{~m}, 1 \mathrm{H}), 2.30-0.50(\mathrm{~m}, 70 \mathrm{H}) \mathrm{ppm} ;{ }^{13} \mathrm{C} \mathrm{NMR}\left(101 \mathrm{MHz}, \mathrm{CDCl}_{3}\right) \delta$ 
215.2, 177.9, 176.5, 127.8, 123.6, 105.9, 99.0, 89.8, 75.2, 74.9, 73.6, 71.5, 71.2, 68.3, 66.2, 56.1, $49.9,49.1,40.7,40.3,39.0,38.7,36.9,36.5,32.7,31.2,30.5,30.1,29.6,27.9,26.3,25.7,22.8$, $22.0,19.9,18.3,18.0,16.9,16.5,15.9,14.2,13.8,13.3,13.1,12.9,12.1,11.9,11.0,6.7,6.4$ ppm; FT-IR (KBr tablet): 3503 (br, m), 2962 (s), 2936 (s), 2857 (m), 1726 (s), 1709 (s), 1460 (m), 1378 (m) $\mathrm{cm}^{-1}$; ESI MS $(m / z):[\mathrm{M}+\mathrm{Na}]^{+}$Calcd for $\mathrm{C}_{53} \mathrm{H}_{84} \mathrm{NaO}_{12}{ }^{+}$935.6; Found 936.

\subsubsection{General procedure for preparation of C20 carbonates of C20-epi-salinomycin (analogues} 12-14)

To a stirred solution of C20-epi-salinomycin intermediate $\mathbf{1}$ (1.0 equiv.) in anhydrous $\mathrm{CH}_{2} \mathrm{Cl}_{2}$ at ambient temperature, the following reagents were added: TEA (6.0 equiv.), an excess of DMAP and the corresponding chloroformate (4.0 equiv.) diluted in anhydrous $\mathrm{CH}_{2} \mathrm{Cl}_{2}$, which was added drop by drop over 30 seconds. The reaction mixtures were stirred overnight at ambient temperature, and then concentrated in vacuo. Purification on silica gel using the CombiFlash system $(0 \rightarrow 30 \% \mathrm{EtOAc} / n$-hexane $)$ gave the intermediate carbonate products as clear oils. In the next step, to a stirred solution of each intermediate product in THF at ambient temperature, TBAF (3.0 equiv., 1.0 $\mathrm{M}$ in THF) was introduced dropwise over 30 seconds. The resulting slightly yellowish solutions were stirred until the starting materials were completely consumed (TLC control) and then concentrated in vacuo. Purification on silica gel using the CombiFlash system $(0 \rightarrow 50 \%$ EtOAc/n-hexane) provided the deprotected products as mixtures of their acid and salt forms. The product mixtures were dissolved again in $\mathrm{CH}_{2} \mathrm{Cl}_{2}$, washed with sulphuric acid $(\mathrm{pH}=$ 1.0), and extracted with water. The organic layers of the reaction mixtures were separated, and evaporated thrice from $n$-pentane to give the pure products $\mathbf{1 2 - 1 4}(10-48 \%$ yield) as white amorphous solids. The ${ }^{1} \mathrm{H}$ and ${ }^{13} \mathrm{C}$ NMR spectra of the newly synthesized carbonates 12, 13 and 
14 can be found in the Supplementary material (Figures S22-S23, Figures S25-S26 and Figures S28-S29, respectively).

C20 ethyl carbonate of C20-epi-salinomycin 12: Yield: $42 \mathrm{mg}, 48 \%$. Isolated as a white amorphous solid, >95\% pure by NMR and a single spot by TLC. Strains green with PMA; ${ }^{1} \mathrm{H}$ NMR (403 MHz, $\left.\mathrm{CD}_{2} \mathrm{Cl}_{2}\right) \delta 6.35(\mathrm{~d}, J=10.6 \mathrm{~Hz}, 1 \mathrm{H}), 6.14(\mathrm{dd}, J=10.6,5.6 \mathrm{~Hz}, 1 \mathrm{H}), 4.78(\mathrm{~d}, J$ $=5.7 \mathrm{~Hz}, 1 \mathrm{H}), 4.13(\mathrm{q}, J=7.1 \mathrm{~Hz}, 2 \mathrm{H}), 4.05(\mathrm{dd}, J=10.2,1.4 \mathrm{~Hz}, 1 \mathrm{H}), 3.92(\mathrm{dd}, J=10.8,5.2 \mathrm{~Hz}$, 1H), $3.86(\mathrm{~d}, J=10.2 \mathrm{~Hz}, 1 \mathrm{H}), 3.79$ (dd, $J=13.9,6.9 \mathrm{~Hz}, 1 \mathrm{H}), 3.58(\mathrm{ddd}, J=7.4,5.3,2.8 \mathrm{~Hz}$, 2H), $2.88(\mathrm{td}, J=10.7,4.0 \mathrm{~Hz}, 1 \mathrm{H}), 2.78-2.69(\mathrm{~m}, 1 \mathrm{H}), 2.60(\mathrm{dd}, J=10.8,2.0 \mathrm{~Hz}, 1 \mathrm{H}), 2.25-0.50$ (m, 59H) ppm; ${ }^{13} \mathrm{C}$ NMR (101 MHz, $\left.\mathrm{CD}_{2} \mathrm{Cl}_{2}\right) \delta 215.2,177.9,154.9,129.1,123.4,106.2,99.3$, $90.2,77.1,75.9,75.2,74.1,71.9,71.3,70.0,68.8,64.4,56.2,49.8,49.1,40.5,39.4,36.8,36.6$, $33.1,32.0,30.1,29.9,28.4,26.6,26.0,23.1,22.2,20.3,18.0,16.7,16.6,14.43,14.42,13.3,13.2$, 12.1, 11.2, 7.0, 6.6 ppm; FT-IR (KBr tablet): 3491 (br, m), 2965 (s), 2939 (s), 2878 (s), 1743 (s), $1717(\mathrm{~s}), 1648(\mathrm{~m}), 1568(\mathrm{~m}), 1461(\mathrm{~s}), 1376(\mathrm{~s}) \mathrm{cm}^{-1}$; ESI MS (m/z): $[\mathrm{M}+\mathrm{Na}]^{+}$Calcd for $\mathrm{C}_{45} \mathrm{H}_{74} \mathrm{NaO}_{13}{ }^{+}$845.5; Found 846 .

C20 neopentyl carbonate of C20-epi-salinomycin 13: Yield: $66 \mathrm{mg}, 32 \%$. Isolated as a white amorphous solid, $>95 \%$ pure by NMR and a single spot by TLC. Strains green with PMA; ${ }^{1} \mathrm{H}$ NMR $\left(401 \mathrm{MHz}, \mathrm{CDCl}_{3}\right) \delta 6.39(\mathrm{~d}, J=10.6 \mathrm{~Hz}, 1 \mathrm{H}), 6.26(\mathrm{dd}, J=10.6,5.7 \mathrm{~Hz}, 1 \mathrm{H}), 4.76(\mathrm{~d}$, $J=5.7 \mathrm{~Hz}, 1 \mathrm{H}), 4.13(\mathrm{~d}, J=10.1 \mathrm{~Hz}, 1 \mathrm{H}), 4.01-3.94(\mathrm{~m}, 1 \mathrm{H}), 3.91-3.85(\mathrm{~m}, 3 \mathrm{H}), 3.83-3.79(\mathrm{~m}$, 1H), $3.74(\mathrm{~d}, J=10.3 \mathrm{~Hz}, 1 \mathrm{H}), 3.69-3.60(\mathrm{~m}, 3 \mathrm{H}), 2.93-2.81(\mathrm{~m}, 1 \mathrm{H}), 2.78-2.68(\mathrm{~m}, 1 \mathrm{H}), 2.60(\mathrm{~d}$, $J=9.7 \mathrm{~Hz}, 1 \mathrm{H}) 2.30-0.50(\mathrm{~m}, 63 \mathrm{H}) \mathrm{ppm} ;{ }^{13} \mathrm{C} \mathrm{NMR}\left(101 \mathrm{MHz}, \mathrm{CDCl}_{3}\right) \delta 215.0,177.9,154.8$, $128.8,123.1,105.6,99.1,90.0,76.5,75.2,74.9,73.8,71.6,71.1,69.7,68.3,56.0,55.9,49.8,49.1$, $40.2,39.3,36.7,36.4,32.7,31.6,31.3,29.9,29.6,28.0,26.2,25.7,22.8,22.0,19.9,18.0,16.5$, 16.4, 15.7, 14.2, 13.2, 12.9, 12.0, 11.0, 6.7, 6.4 ppm; FT-IR (KBr tablet): 3506 (br, m), 2962 (s), 
2939 (s), 2877 (m), 1755 (s), 1709 (s), 1633 (w), 1457 (m), 1387 (s) cm ${ }^{-1}$; ESI MS (m/z): [M+Na] Calcd for $\mathrm{C}_{48} \mathrm{H}_{80} \mathrm{NaO}_{13}{ }^{+}$887.5; Found 888 .

C20 phenyl carbonate of C20-epi-salinomycin 14: Yield: $21 \mathrm{mg}, 10 \%$. Isolated as a white amorphous solid, $>95 \%$ pure by NMR and a single spot by TLC. UV-active and strains green with PMA; ${ }^{1} \mathrm{H}$ NMR (401 MHz, $\left.\mathrm{CDCl}_{3}\right) \delta$ 7.39-7.33 (m, 2H), 7.25-7.19 (m, 1H), 7.15-7.11 (m, 2H), $6.45(\mathrm{~d}, J=10.7 \mathrm{~Hz}, 1 \mathrm{H}), 6.28(\mathrm{dd}, J=10.6,5.8 \mathrm{~Hz}, 1 \mathrm{H}), 4.91(\mathrm{~d}, J=5.8 \mathrm{~Hz}, 1 \mathrm{H}), 4.13(\mathrm{dd}, J=$ 8.7, $4.2 \mathrm{~Hz}, 1 \mathrm{H}), 3.97(\mathrm{dd}, J=10.6,5.1 \mathrm{~Hz}, 1 \mathrm{H}), 3.92(\mathrm{~d}, J=10.3 \mathrm{~Hz}, 1 \mathrm{H}), 3.83(\mathrm{~d}, J=6.4 \mathrm{~Hz}$, $1 \mathrm{H}), 3.68(\mathrm{dd}, J=10.2,3.2 \mathrm{~Hz}, 1 \mathrm{H}), 3.65-3.61(\mathrm{~m}, 1 \mathrm{H}), 2.88(\mathrm{td}, J=10.9,3.8 \mathrm{~Hz}, 1 \mathrm{H}), 2.78-2.70$ $(\mathrm{m}, 1 \mathrm{H}), 2.62-2.55(\mathrm{~m}, 1 \mathrm{H}), 2.30-2.19(\mathrm{~m}, 1 \mathrm{H}), 2.16-2.04(\mathrm{~m}, 2 \mathrm{H}), 2.00-0.50(\mathrm{~m}, 53 \mathrm{H}) \mathrm{ppm} ;{ }^{13} \mathrm{C}$ NMR $\left(101 \mathrm{MHz}, \mathrm{CDCl}_{3}\right) \delta 214.9,177.8,153.1,151.1,129.5,129.4,126.0,122.4,121.1,105.4$ $99.0,90.2,76.5,75.2,74.9,73.8,71.6,71.2,70.7,68.3,56.0,49.7,49.0,40.1,39.2,36.8,36.4$, $32.7,31.3,29.9,29.6,28.0,26.3,25.7,22.7,22.1,19.9,18.0,16.5,16.3,14.2,13.3,12.9,12.0$, 11.0, 6.7, 6.4 ppm; FT-IR (KBr tablet): 3491 (br, m), 2971 (s), 2933 (s), 2880 (s), 1764 (s), 1712 (s), $1644(w), 1597(w), 1568(w), 1466(\mathrm{~m}), 1387(\mathrm{~m}) \mathrm{cm}^{-1}$; ESI MS (m/z): [M+Na] $]^{+}$Calcd for $\mathrm{C}_{49} \mathrm{H}_{74} \mathrm{NaO}_{13}{ }^{+}$893.5; Found 894.

4.2.6. General procedure for preparation of C20 carbamates and C2O allophanate of C20-episalinomycin (analogues 15-18)

To a stirred solution of C20-epi-salinomycin intermediate 1 (1.0 equiv.) in anhydrous DMF at ambient temperature, the respective isocyanate (2.0 equiv.) was added drop by drop over 30 seconds, followed by the addition of one spatula tip-full of anhydrous, freshly ground $\mathrm{CuCl}$ in one portion. The greenish reaction mixture was stirred for three days at ambient temperature, and then concentrated in vacuo. Purification on silica gel using the CombiFlash system $(0 \rightarrow 30 \%$ EtOAc/n- 
hexane) gave the intermediate carbamate/allophanate products as clear oils. In the next step, to a stirred solution of each intermediate product in THF at ambient temperature, TBAF (3.0 equiv., 1.0 $\mathrm{M}$ in THF) was introduced dropwise over 30 seconds. The resulting slightly yellowish solutions were stirred until the starting materials were completely consumed (TLC control) and then concentrated in vacuo. Purification on silica gel using the CombiFlash system $(0 \rightarrow 50 \%$ EtOAc/n-hexane) provided the deprotected products as mixtures of their acid and salt forms. The product mixtures were dissolved again in $\mathrm{CH}_{2} \mathrm{Cl}_{2}$, washed with aqueous solution of $\mathrm{Na}_{2} \mathrm{CO}_{3}(0.1$ $\mathrm{M})$ in the case of $\mathbf{1 6}$ and $\mathbf{1 8}$, or with sulphuric acid $(\mathrm{pH}=1.0)$ in the case of $\mathbf{1 5}$ and $\mathbf{1 7}$, and extracted with water. The organic layers of the reaction mixtures were separated, and evaporated thrice from $n$-pentane to give the pure products 15-18 (15-49\% yield) as white amorphous solids. The NMR spectra of the newly synthesized carbamates $\mathbf{1 5 - 1 7}$, and the newly synthesized allophanate $\mathbf{1 8}$ can be found in the Supplementary material (Figures S31-S32, Figures S34-S35, Figures S37-S38, Figures S40-S41 and Figures S43-S45, respectively).

C20 octyl carbamate of C20-epi-salinomycin 15: Yield: $33 \mathrm{mg}, 15 \%$. Isolated as a white amorphous solid, >95\% pure by NMR and a single spot by TLC. Strains green with PMA; ${ }^{1} \mathrm{H}$ $\operatorname{NMR}\left(401 \mathrm{MHz}, \mathrm{CDCl}_{3}\right) \delta 6.11(\mathrm{dd}, J=10.9,2.6 \mathrm{~Hz}, 1 \mathrm{H}), 5.91(\mathrm{t}, J=6.2 \mathrm{~Hz}, 1 \mathrm{H}), 5.79(\mathrm{dd}, J=$ $10.9,1.5 \mathrm{~Hz}, 1 \mathrm{H}), 5.24(\mathrm{dd}, J=2.5,1.7 \mathrm{~Hz}, 1 \mathrm{H}), 4.13(\mathrm{~d}, J=10.1 \mathrm{~Hz}, 1 \mathrm{H}), 3.98(\mathrm{dd}, J=10.6,5.5$ Hz, 1H), 3.89 (q, $J=6.7 \mathrm{~Hz}, 1 \mathrm{H}), 3.83(\mathrm{~d}, J=10.3 \mathrm{~Hz}, 1 \mathrm{H}), 3.69-3.60(\mathrm{~m}, 1 \mathrm{H}), 3.44(\mathrm{dd}, J=6.4$, $3.7 \mathrm{~Hz}, 1 \mathrm{H}), 3.22-3.04(\mathrm{~m}, 2 \mathrm{H}), 2.89(\mathrm{td}, J=11.0,3.8 \mathrm{~Hz}, 1 \mathrm{H}), 2.77-2.67(\mathrm{~m}, 1 \mathrm{H}), 2.56(\mathrm{~d}, J=$ $8.9 \mathrm{~Hz}, 1 \mathrm{H}), 2.00-0.50(\mathrm{~m}, 71 \mathrm{H}) \mathrm{ppm} ;{ }^{13} \mathrm{C} \mathrm{NMR}\left(101 \mathrm{MHz}, \mathrm{CDCl}_{3}\right) \delta$ 213.6, 177.9, 156.0, 127.6, 123.1, 104.7, 99.1, 87.9, 75.9, 75.5, 75.1, 73.6, 71.6, 71.1, 68.3, 67.4, 56.1, 49.9, 48.3, 41.1, 41.0, $38.7,36.3,36.2,32.8,32.6,31.8,30.6,29.9,29.7,29.3,29.2,29.0,28.0,26.8,26.5,26.4,22.6$, 22.5, 20.4, 17.9, 16.3, 15.8, 14.12, 14.06, 13.4, 13.0, 12.0, 11.2, 7.0, 6.4 ppm; FT-IR (KBr tablet): 
3459 (br, m), 2959 (s), 2930 (s), 2875 (m), 1711 (s), 1534 (m), 1466 (m), 1384 (m) cm cm $^{-1}$ ESI MS $(\mathrm{m} / z):[\mathrm{M}+\mathrm{Na}]^{+} \mathrm{Calcd}$ for $\mathrm{C}_{51} \mathrm{H}_{87} \mathrm{NNaO}_{21}{ }^{+}$928.6; Found 929 .

C20 tert-butyl carbamate of C20-epi-salinomycin 16: Yield: $45 \mathrm{mg}$, 49\%. Isolated as a white amorphous solid, >95\% pure by NMR and a single spot by TLC. Strains green with PMA; ${ }^{1} \mathrm{H}$ NMR $\left(401 \mathrm{MHz}, \mathrm{CDCl}_{3}\right) \delta 6.34(\mathrm{~d}, J=10.7 \mathrm{~Hz}, 1 \mathrm{H}), 6.24(\mathrm{dd}, J=10.6,5.7 \mathrm{~Hz}, 1 \mathrm{H}), 4.94(\mathrm{~s}$, 1H), $4.44(\mathrm{~s}, 1 \mathrm{H}), 4.33(\mathrm{~d}, J=6.8 \mathrm{~Hz}, 1 \mathrm{H}), 4.20(\mathrm{~d}, J=10.1 \mathrm{~Hz}, 1 \mathrm{H}), 3.89$ (dd, $J=11.1,4.3 \mathrm{~Hz}$, 1H), $3.68(\mathrm{~d}, J=10.2 \mathrm{~Hz}, 1 \mathrm{H}), 3.57(\mathrm{~d}, J=10.2 \mathrm{~Hz}, 1 \mathrm{H}), 3.35(\mathrm{~d}, J=11.0 \mathrm{~Hz}, 1 \mathrm{H}), 2.82(\mathrm{td}, J=$ $10.7,2.8 \mathrm{~Hz}, 1 \mathrm{H}), 2.73-2.56(\mathrm{~m}, 2 \mathrm{H}), 2.20-0.50(\mathrm{~m}, 61 \mathrm{H}) \mathrm{ppm} ;{ }^{13} \mathrm{C} \mathrm{NMR}\left(101 \mathrm{MHz}, \mathrm{CDCl}_{3}\right) \delta$ $216.9,184.2,153.6,127.1,124.5,106.8,99.0,89.4,76.5,75.9,75.8,75.0,74.2,71.4,69.9,67.2$ $65.1,55.3,51.1,50.4,50.3,40.0,39.0,35.9,32.7,32.4,32.2,28.9,28.8,28.0,27.8,26.9,23.8$, 20.5, 20.0, 17.5, 16.5, 16.0, 14.5, 13.2, 12.4, 11.8, 10.6, 6.7, 6.4 ppm; FT-IR (KBr tablet): 3295 (br, m), 2959 (s), 2930 (s), 2875 (m), 1730 (s), 1714 (s), 1672 (w), 1571 (s), 1534 (m), 1460 (s), $1408(\mathrm{~m}) \mathrm{cm}^{-1}$; ESI MS (m/z): $[\mathrm{M}+\mathrm{H}]^{+}$Calcd for $\mathrm{C}_{47} \mathrm{H}_{75} \mathrm{NNaO}_{12}{ }^{+}$872.5; Found 873.

C20 phenyl carbamate of C20-epi-salinomycin 17: Yield: $58 \mathrm{mg}, 23 \%$. Isolated as a white amorphous solid, $>95 \%$ pure by NMR and a single spot by TLC. UV-active and strains green with PMA; ${ }^{1} \mathrm{H}$ NMR (401 MHz, $\left.\mathrm{CDCl}_{3}\right) \delta 7.36(\mathrm{~d}, J=7.5 \mathrm{~Hz}, 2 \mathrm{H}), 7.29(\mathrm{t}, J=7.0 \mathrm{~Hz}, 2 \mathrm{H}), 7.05(\mathrm{dd}$, $J=9.1,5.4 \mathrm{~Hz}, 1 \mathrm{H}), 6.45(\mathrm{~s}, 1 \mathrm{H}), 6.39(\mathrm{~d}, J=10.6 \mathrm{~Hz}, 1 \mathrm{H}), 6.25(\mathrm{dd}, J=10.5,5.7 \mathrm{~Hz}, 1 \mathrm{H}), 4.99$ $(\mathrm{d}, J=5.7 \mathrm{~Hz}, 1 \mathrm{H}), 4.13(\mathrm{~d}, J=10.1 \mathrm{~Hz}, 1 \mathrm{H}), 3.97(\mathrm{dd}, J=10.8,5.5 \mathrm{~Hz}, 1 \mathrm{H}), 3.90(\mathrm{~d}, J=10.4$ $\mathrm{Hz}, 1 \mathrm{H}), 3.84(\mathrm{q}, J=6.6 \mathrm{~Hz}, 1 \mathrm{H}), 3.65(\mathrm{dd}, J=14.2,6.5 \mathrm{~Hz}, 2 \mathrm{H}), 2.89(\mathrm{td}, J=10.8,3.5 \mathrm{~Hz}, 1 \mathrm{H})$, $2.74(\mathrm{dd}, J=9.9,7.2 \mathrm{~Hz}, 1 \mathrm{H}), 2.65-2.58(\mathrm{~m}, 1 \mathrm{H}), 2.40-0.50(\mathrm{~m}, 56 \mathrm{H}) \mathrm{ppm} ;{ }^{13} \mathrm{C}$ NMR $(101 \mathrm{MHz}$, $\left.\mathrm{CDCl}_{3}\right) \delta 215.0,177.8,152.7,137.6,129.0,128.2,123.8,123.5,118.8,106.0,99.0,90.0,76.4$ $75.3,74.9,73.7,71.5,71.2,68.3,67.3,56.0,49.8,49.0,40.1,39.1,36.6,36.4,32.7,31.4,29.8$ 29.6, 28.0, 26.3, 25.6, 22.8, 22.1, 19.9, 17.9, 16.8, 16.5, 14.2, 13.2, 12.9, 12.0, 11.0, 6.7, 6.4 ppm; 
FT-IR (KBr tablet): 3441 (br, m), 3360 (br, m), 2968 (s), 2933 (s), 2875 (m), 1714 (s), 1600 (m), $1538(\mathrm{~m}), 1527(\mathrm{~m}), 1503(\mathrm{~m}), 1457(\mathrm{~m}), 1437(\mathrm{~m}), 1381(\mathrm{~m}) \mathrm{cm}^{-1}$; ESI MS (m/z): [M+Na] $]^{+}$Calcd for $\mathrm{C}_{49} \mathrm{H}_{75} \mathrm{NNaO}_{12}{ }^{+}$892.5; Found 893 .

C20 allophanate of C20-epi-salinomycin 18: Yield: $48 \mathrm{mg}, 39 \%$. Isolated as a white amorphous solid, >95\% pure by NMR and a single spot by TLC. Strains green with PMA; ${ }^{1} \mathrm{H}$ NMR (400 MHz, $\left.\mathrm{CD}_{2} \mathrm{Cl}_{2}\right) \delta 8.48(\mathrm{t}, J=5.2 \mathrm{~Hz}, 1 \mathrm{H}), 6.42(\mathrm{~d}, J=10.7 \mathrm{~Hz}, 1 \mathrm{H}), 6.15(\mathrm{dd}, J=10.6$, $5.7 \mathrm{~Hz}, 1 \mathrm{H}), 5.20(\mathrm{~s}, J=53.8 \mathrm{~Hz}, 2 \mathrm{H}), 4.99(\mathrm{~d}, J=5.7 \mathrm{~Hz}, 1 \mathrm{H}), 4.28(\mathrm{dd}, J=13.1,6.2 \mathrm{~Hz}, 1 \mathrm{H})$, $4.09(\mathrm{~d}, J=10.9 \mathrm{~Hz}, 1 \mathrm{H}), 3.77(\mathrm{dd}, J=10.9,4.6 \mathrm{~Hz}, 1 \mathrm{H}), 3.73-3.58(\mathrm{~m}, 3 \mathrm{H}), 3.40(\mathrm{dd}, J=12.0$, $2.1 \mathrm{~Hz}, 1 \mathrm{H}), 3.26(\mathrm{qd}, J=7.2,5.5 \mathrm{~Hz}, 2 \mathrm{H}), 2.82-2.61(\mathrm{~m}, 3 \mathrm{H}), 2.15-0.50(\mathrm{~m}, 61 \mathrm{H}) \mathrm{ppm} ;{ }^{13} \mathrm{C} \mathrm{NMR}$ $\left(101 \mathrm{MHz}, \mathrm{CD}_{2} \mathrm{Cl}_{2}\right) \delta 218.4,184.2,155.8,154.1,128.9,123.3,106.5,99.4,90.2,76.5,76.1,75.6$, 74.6, 71.6, 70.0, 68.3, 67.7, 55.9, 51.4, 50.5, 40.4, 39.1, 37.0, 36.3, 35.8, 33.0, 32.8, 32.7, 30.1, $29.4,28.4,28.0,27.2,24.1,21.2,20.3,17.6,16.4,16.2,15.1,14.9,14.6,13.2,12.6,12.3,10.8$, 6.8, 6.6 ppm; FT-IR (KBr tablet): 3494 (br, m), 3348 (br, m), 2968 (s), 2936 (s), 2877 (m), 1720 (s), $1679(\mathrm{~m}), 1562(\mathrm{~m}), 1539(\mathrm{~m}), 1457(\mathrm{~m}), 1387(\mathrm{~s}) \mathrm{cm}^{-1}$; ESI MS (m/z): $[\mathrm{M}+\mathrm{H}]^{+}$Calcd for $\mathrm{C}_{48} \mathrm{H}_{80} \mathrm{~N}_{2} \mathrm{NaO}_{13}{ }^{+}$915.56; Found 915.68.

4.2.7. General procedure for preparation of $C 1$ propargyl amides of $C 20$ acetate or C20 ethyl carbonate of C20-epi-salinomycin (analogues 19 and 23)

To a stirred solution of $\mathbf{7}$ or $\mathbf{1 2}$ (1.0 equiv.) in anhydrous $\mathrm{CH}_{2} \mathrm{Cl}_{2}$ at $0{ }^{\circ} \mathrm{C}$, the following reagents were added: DCC (1.2 equiv.), HOBt (0.5 equiv., dissolved in a few $\mathrm{mL}$ of THF) and propargylamine (2.5 equiv.). The reaction mixtures were warmed to room temperature, stirred for $48 \mathrm{~h}$, and then concentrated in vacuo. Purification on silica gel using the CombiFlash system $(0 \rightarrow 30 \%$ EtOAc/n-hexane) gave the pure products 19 (44\% yield) and $\mathbf{2 3}$ (42\% yield) as clear 
oils. After thrice evaporation to dryness with $n$-pentane, the oily products were completely converted into white amorphous solids. The ${ }^{1} \mathrm{H}$ and ${ }^{13} \mathrm{C}$ NMR spectra of $\mathrm{C} 1 / \mathrm{C} 20$ doubly modified analogues 19 and $\mathbf{2 3}$ can be found in the Supplementary material (Figures S46-S47 and Figures S58-S59, respectively).

Cl propargyl amide of C20 acetate of C20-epi-salinomycin 19: Yield: $50 \mathrm{mg}, 44 \%$. Isolated as a white amorphous solid, >95\% pure by NMR and a single spot by TLC. Strains green with PMA; ${ }^{1} \mathrm{H}$ NMR (401 MHz, $\left.\mathrm{CDCl}_{3}\right) \delta 6.91(\mathrm{t}, J=5.5 \mathrm{~Hz}, 1 \mathrm{H}), 6.40(\mathrm{~d}, J=10.6 \mathrm{~Hz}, 1 \mathrm{H}), 6.19$ $(\mathrm{dd}, J=10.5,5.5 \mathrm{~Hz}, 1 \mathrm{H}), 4.90(\mathrm{~d}, J=5.5 \mathrm{~Hz}, 1 \mathrm{H}), 4.41(\mathrm{ddd}, J=17.5,5.9,2.5 \mathrm{~Hz}, 1 \mathrm{H}), 4.19$ (ddd, $J=17.6,4.9,2.5 \mathrm{~Hz}, 1 \mathrm{H}), 4.11(\mathrm{~d}, J=9.6 \mathrm{~Hz}, 1 \mathrm{H}), 4.02-3.92(\mathrm{~m}, 1 \mathrm{H}), 3.76(\mathrm{q}, J=6.5 \mathrm{~Hz}$, 1H), $3.68(\mathrm{~d}, J=9.9 \mathrm{~Hz}, 2 \mathrm{H}), 3.42(\mathrm{dd}, J=9.1,4.8 \mathrm{~Hz}, 1 \mathrm{H}), 2.95(\mathrm{dq}, J=14.8,7.4 \mathrm{~Hz}, 1 \mathrm{H}), 2.78$ (s, 1H), $2.67(\mathrm{tt}, J=12.7,6.3 \mathrm{~Hz}, 1 \mathrm{H}), 2.64-2.56(\mathrm{~m}, 1 \mathrm{H}), 2.31-2.24(\mathrm{~m}, 1 \mathrm{H}), 2.10(\mathrm{t}, J=2.5 \mathrm{~Hz}$ 1H), $2.00-0.50(\mathrm{~m}, 57 \mathrm{H}) \mathrm{ppm} ;{ }^{13} \mathrm{C} \mathrm{NMR}\left(101 \mathrm{MHz}, \mathrm{CDCl}_{3}\right) \delta 213.1,174.8,170.2,127.0,125.3$, 106.0, 98.4, 89.2, 81.3, 79.8, 76.7, 75.1, 73.6, 71.1, 70.9, 69.9, 69.1, 67.2, 54.5, 48.1, 46.9, 39.6, $38.8,36.7,36.2,32.7,31.5,30.4,29.4,28.8,28.3,26.6,25.1,22.2,21.6,20.9,20.4,18.2,17.3$, 16.2, 14.4, 14.3, 13.9, 11.8, 11.5, 8.0, 6.4 ppm; FT-IR (KBr tablet): 3503 (m), 3447 (br, m), 3348 (m), 3312 (m), 3287 (m), 2968 (s), 2936 (s), 2875 (m), 2234 (m), 1744 (s), 1709 (m), 1659 (s), $1527(\mathrm{~m}), 1463(\mathrm{~s}), 1378(\mathrm{~s}) \mathrm{cm}^{-1}$; ESI MS (m/z): [M+Na $]^{+}$Calcd for $\mathrm{C}_{47} \mathrm{H}_{75} \mathrm{NNaO}_{11}{ }^{+}$852.5; Found 853.

C1 propargyl amide of C20 ethyl carbonate of C20-epi-salinomycin 23: Yield: $47 \mathrm{mg}$, $42 \%$. Isolated as a white amorphous solid, $>95 \%$ pure by NMR and a single spot by TLC. Strains green with PMA; ${ }^{1} \mathrm{H}$ NMR $\left(403 \mathrm{MHz}, \mathrm{CD}_{2} \mathrm{Cl}_{2}\right) \delta 7.01(\mathrm{t}, J=5.2 \mathrm{~Hz}, 1 \mathrm{H}), 6.46(\mathrm{~d}, J=10.6 \mathrm{~Hz}$, 1H), $6.20(\mathrm{dd}, J=10.5,5.3 \mathrm{~Hz}, 1 \mathrm{H}), 4.81(\mathrm{~d}, J=5.3 \mathrm{~Hz}, 1 \mathrm{H}), 4.34(\mathrm{ddd}, J=17.5,5.9,2.4 \mathrm{~Hz}$, $1 \mathrm{H}), 4.23-4.10(\mathrm{~m}, 4 \mathrm{H}), 4.05(\mathrm{~d}, J=9.4 \mathrm{~Hz}, 1 \mathrm{H}), 3.90(\mathrm{dd}, J=9.2,5.1 \mathrm{~Hz}, 1 \mathrm{H}), 3.80-3.62(\mathrm{~m}$, 
4H), 3.46-3.37 (m, 1H), 2.95-2.78 (m, 3H), 2.69 (td, $J=10.6,3.9 \mathrm{~Hz}, 1 \mathrm{H}), 2.58(\mathrm{dt}, J=8.9,2.3$ $\mathrm{Hz}, 1 \mathrm{H}), 2.15(\mathrm{t}, J=2.4 \mathrm{~Hz}, 1 \mathrm{H}), 2.14-0.50(\mathrm{~m}, 55 \mathrm{H}) \mathrm{ppm} ;{ }^{13} \mathrm{C} \mathrm{NMR}\left(101 \mathrm{MHz}, \mathrm{CD}_{2} \mathrm{Cl}_{2}\right) \delta 213.7$, $175.4,155.2,128.2,125.7,106.8,99.0,89.9,82.2,80.1,77.6,75.8,74.2,71.7,71.3,70.6,70.0$ $69.7,64.8,54.5,48.5,47.0,40.2,39.2,37.0,36.8,33.2,32.2,31.1,30.0,29.2,28.9,27.2,25.6$, 22.8, 22.2, 20.9, 18.1, 17.6, 16.6, 14.9, 14.8, 14.6, 14.4, 12.1, 11.7, 8.4, 6.9 ppm; FT-IR (KBr tablet): 3479 (br, m), 3353 (br, m), 3313 (m), 2965 (s), 2935 (s), 2877 (s), 2122 (w), 1744 (s), 1712 (s), 1659 (s), 1528 (s), 1460 (s), 1373 (s) cm ${ }^{-1}$; ESI MS (m/z): [M+Na] $]^{+}$Calcd for $\mathrm{C}_{48} \mathrm{H}_{77} \mathrm{NNaO}_{12}{ }^{+}$ 882.5; Found 883.

4.2.8. General procedure for preparation of C1 propargyl esters of C20 acetate or C2O ethyl carbonate of C20-epi-salinomycin (analogues 20 and 24)

To a stirred solution of $\mathbf{7}$ or $\mathbf{1 2}$ (1.0 equiv.) in anhydrous toluene, DBU (1.2 equiv.) and propargyl bromide ( $~ 80 \%$ in toluene) (3.0 equiv.) were added and the solutions were heated at 90 ${ }^{\circ} \mathrm{C}$ for $6 \mathrm{~h}$. Each solution was then concentrated in vacuo. Purification on silica gel using the CombiFlash system $(0 \rightarrow 50 \%$ EtOAc/ $n$-hexane) gave the pure products 20 (57\% yield) and 24 (35\% yield) as clear oils. After thrice evaporation to dryness with $n$-pentane, the oily products were completely converted into white amorphous solids. The ${ }^{1} \mathrm{H}$ and ${ }^{13} \mathrm{C}$ NMR spectra of C1/C20 doubly modified analogues $\mathbf{2 0}$ and $\mathbf{2 4}$ can be found in the Supplementary material (Figures S49S50 and Figures S61-S62, respectively).

C1 propargyl ester of C20 acetate of C20-epi-salinomycin 20: Yield: $66 \mathrm{mg}, 57 \%$. Isolated as a white amorphous solid, $>95 \%$ pure by NMR and a single spot by TLC. Strains green with PMA; ${ }^{1} \mathrm{H}$ NMR $\left(401 \mathrm{MHz}, \mathrm{CDCl}_{3}\right) \delta 6.38(\mathrm{~d}, J=10.6 \mathrm{~Hz}, 1 \mathrm{H}), 6.21(\mathrm{dd}, J=10.5,5.7 \mathrm{~Hz}, 1 \mathrm{H})$, $5.02(\mathrm{dd}, J=15.9,2.4 \mathrm{~Hz}, 1 \mathrm{H}), 4.87(\mathrm{dt}, J=14.3,3.3 \mathrm{~Hz}, 1 \mathrm{H}), 4.06(\mathrm{dd}, J=10.9,5.7 \mathrm{~Hz}, 1 \mathrm{H})$, 
$3.97(\mathrm{dd}, J=9.8,4.9 \mathrm{~Hz}, 1 \mathrm{H}), 3.79-3.71(\mathrm{~m}, 1 \mathrm{H}), 3.64(\mathrm{dd}, J=9.7,1.5 \mathrm{~Hz}, 1 \mathrm{H}), 3.58(\mathrm{dd}, J=$ 10.5, 2.2 Hz, 1H), 3.45-3.40 (m, 1H), $3.15(\mathrm{dq}, J=14.5,7.3 \mathrm{~Hz}, 1 \mathrm{H}), 3.05(\mathrm{td}, J=10.9,4.3 \mathrm{~Hz}$ $1 \mathrm{H}), 2.76-2.68(\mathrm{~m}, 2 \mathrm{H}), 2.59(\mathrm{~s}, 1 \mathrm{H}), 2.46(\mathrm{t}, J=2.4 \mathrm{~Hz}, 1 \mathrm{H}), 2.20-0.50(\mathrm{~m}, 58 \mathrm{H}) \mathrm{ppm} ;{ }^{13} \mathrm{C} \mathrm{NMR}$ $\left(101 \mathrm{MHz}, \mathrm{CDCl}_{3}\right) \delta 213.8,174.5,170.2,127.5,124.4,105.7,98.6,88.4,80.2,78.2,76.8,74.7$, $73.4,71.8,70.9,69.2,67.5,57.1,52.5,48.3,48.1,39.6,39.3,36.5,36.4,33.1,31.8,30.4,29.3$, $28.3,26.2,24.5,22.7,21.6,20.9,20.5,19.7,17.5,16.2,14.3,13.9,13.0,11.6,11.0,7.3,6.4 \mathrm{ppm}$, one signal overlapped; FT-IR (KBr tablet): 3541 (br, m), 3313 (br, m), 3254 (br, m), 2968 (s), $2939(\mathrm{~s}), 2875(\mathrm{~m}), 2125(\mathrm{w}), 1732(\mathrm{~s}), 1626(\mathrm{w}), 1463(\mathrm{~s}), 1378(\mathrm{~s}) \mathrm{cm}^{-1}$; ESI MS (m/z): [M+Na] $]^{+}$ Calcd for $\mathrm{C}_{47} \mathrm{H}_{74} \mathrm{NaO}_{12}{ }^{+}$853.5; Found 854 .

C1 propargyl ester of C20 ethyl carbonate of C20-epi-salinomycin 24: Yield: $58 \mathrm{mg}, 35 \%$. Isolated as a white amorphous solid, >95\% pure by NMR and a single spot by TLC. Strains green with PMA; ${ }^{1} \mathrm{H}$ NMR $\left(403 \mathrm{MHz}, \mathrm{CD}_{2} \mathrm{Cl}_{2}\right) \delta 6.39(\mathrm{~d}, J=10.6 \mathrm{~Hz}, 1 \mathrm{H}), 6.20(\mathrm{dd}, J=10.5,5.5 \mathrm{~Hz}$, 1H), $5.31(\mathrm{~s}, 1 \mathrm{H}), 4.91(\mathrm{t}, J=2.9 \mathrm{~Hz}, 2 \mathrm{H}), 4.76(\mathrm{~d}, J=5.5 \mathrm{~Hz}, 1 \mathrm{H}), 4.14(\mathrm{q}, J=7.1 \mathrm{~Hz}, 2 \mathrm{H}), 3.98$ $(\mathrm{dd}, J=11.0,5.9 \mathrm{~Hz}, 1 \mathrm{H}), 3.90(\mathrm{dd}, J=9.8,2.9 \mathrm{~Hz}, 1 \mathrm{H}), 3.72(\mathrm{q}, J=6.9 \mathrm{~Hz}, 1 \mathrm{H}), 3.64-3.55(\mathrm{~m}$, 2H), $3.42(\mathrm{dd}, J=10.7,2.8 \mathrm{~Hz}, 1 \mathrm{H}), 3.10-2.98(\mathrm{~m}, 2 \mathrm{H}), 2.66(\mathrm{dt}, J=10.1,2.6 \mathrm{~Hz}, 1 \mathrm{H}), 2.54(\mathrm{dd}$, $J=11.2,8.8 \mathrm{~Hz}, 3 \mathrm{H}), 2.15-2.02(\mathrm{~m}, 2 \mathrm{H}), 2.00-0.50(\mathrm{~m}, 54 \mathrm{H}) \mathrm{ppm} ;{ }^{13} \mathrm{C} \mathrm{NMR}\left(101 \mathrm{MHz}, \mathrm{CD}_{2} \mathrm{Cl}_{2}\right)$ $\delta 214.2,174.9,155.0,128.4,124.5,106.1,99.0,88.8,80.0,78.7,77.3,75.0,74.9,73.6,72.2,71.1$, 70.6, 69.6, 64.4, 56.9, 52.7, 48.8, 48.1, 40.0, 39.5, 36.7, 36.6, 33.4, 32.3, 30.9, 29.7, 28.5, 26.6, 24.8, 23.2, 21.9, 20.1, 20.0, 17.6, 16.5, 14.5, 14.4, 14.1, 13.3, 11.8, 11.1, 7.5, 6.6 ppm; FT-IR (KBr tablet): 3545 (br, m), 3458 (br, m), 3311 (m), 2965 (s), 2939 (s), 2877 (s), 2129 (w), 1743 (s), 1713 (s), 1630 (w), 1461 (s), 1374 (s) cm ${ }^{-1}$; ESI MS (m/z): [M+Na $]^{+}$Calcd for $\mathrm{C}_{48} \mathrm{H}_{76} \mathrm{NaO}_{13}{ }^{+}$883.5; Found 883 . 
4.2.9. General procedure for preparation of C1 esters of C2O acetate of C2O-epi-salinomycin with hydroxamic acids (analogues 21 and 22)

To a stirred solution of 7 (1.0 equiv.) in anhydrous $\mathrm{CH}_{2} \mathrm{Cl}_{2}$ at ambient temperature, DCC (2.0 equiv.) and DMAP (2.0 equiv.) were introduced, and then the respective hydroxamic acid (5.0 equiv.) was added in one portion. The resulting solutions were stirred for $48 \mathrm{~h}$, diluted with $\mathrm{CH}_{2} \mathrm{Cl}_{2}$ and then washed with saturated $\mathrm{NH}_{4} \mathrm{Cl}$. The organic layers of the reaction mixtures were separated and concentrated in vacuo to give clear oils. Purification on silica gel using the CombiFlash system $(0 \rightarrow 30 \%$ EtOAc/ $n$-hexane) gave the pure products 21 and $\mathbf{2 2}$ (17-27\% yield) as clear oils. After thrice evaporation to dryness with $n$-pentane, the oily products were completely converted into white amorphous solids. The ${ }^{1} \mathrm{H}$ and ${ }^{13} \mathrm{C}$ NMR spectra of esters $\mathbf{2 1}$ and $\mathbf{2 2}$ can be found in the Supplementary material (Figures S52-S53 and Figures S55-S56, respectively).

C1 benzhydroxamic acid ester of C20 acetate of C20-epi-salinomycin 21: Yield: $31 \mathrm{mg}$, 27\%. Isolated as a white amorphous solid, >95\% pure by NMR and a single spot by TLC. UVactive and strains green with PMA; ${ }^{1} \mathrm{H}$ NMR $\left(400 \mathrm{MHz}, \mathrm{CD}_{2} \mathrm{Cl}_{2}\right) \delta 11.04(\mathrm{~s}, J=12.0 \mathrm{~Hz}, 1 \mathrm{H})$, 8.21-8.09 (m, 2H), 7.57-7.49 (m, 1H), 7.49-7.38 (m, 2H), 6.40 (d, $J=10.6 \mathrm{~Hz}, 1 \mathrm{H}), 6.16(\mathrm{dd}, J$ $=10.5,5.5 \mathrm{~Hz}, 1 \mathrm{H}), 4.80(\mathrm{~d}, J=5.5 \mathrm{~Hz}, 1 \mathrm{H}), 4.03(\mathrm{ddd}, J=23.0,12.0,7.2 \mathrm{~Hz}, 2 \mathrm{H}), 3.83(\mathrm{dd}, J=$ 10.1, $2.4 \mathrm{~Hz}, 1 \mathrm{H}), 3.77-3.68(\mathrm{~m}, 2 \mathrm{H}), 3.48(\mathrm{dd}, J=12.0,2.2 \mathrm{~Hz}, 1 \mathrm{H}), 3.21-3.11(\mathrm{~m}, 1 \mathrm{H}), 2.95(\mathrm{dt}$, $J=17.3,7.4 \mathrm{~Hz}, 1 \mathrm{H}), 2.64(\mathrm{~s}, 1 \mathrm{H}), 2.56(\mathrm{dd}, J=7.2,2.2 \mathrm{~Hz}, 1 \mathrm{H}), 2.20-2.14(\mathrm{~m}, 1 \mathrm{H}), 2.20-0.50$ (m, 57H) ppm; ${ }^{13} \mathrm{C}$ NMR $\left(101 \mathrm{MHz}, \mathrm{CD}_{2} \mathrm{Cl}_{2}\right) \delta 216.0,173.9,170.3,165.4,132.3,131.5,128.6$, $128.3,126.8,126.0,106.2,98.8,90.1,80.1,77.0,75.0,73.4,72.3,71.1,68.9,67.4,53.9,46.6$, $46.4,40.1,38.7,37.2,36.7,32.8,31.1,31.0,29.9,28.6,26.8,25.8,23.6,22.2,21.0,20.1,17.2$, 17.0, 16.3, 14.9, 14.7, 12.0, 11.0, 7.9, 6.7 ppm, one signal overlapped; FT-IR (KBr tablet): 3509 (br, m), 3313 (br, m), 2959 (s), 2936 (s), 2880 (m), 1785 (s), 1741 (m), 1703 (s), 1697 (m), 1604 
(w), $1583(\mathrm{w}), 1504(\mathrm{w}), 1463(\mathrm{~m}), 1373(\mathrm{~m}) \mathrm{cm}^{-1}$; ESI MS (m/z): $[\mathrm{M}+\mathrm{Na}]^{+}$Calcd for $\mathrm{C}_{51} \mathrm{H}_{77} \mathrm{NNaO}_{13}{ }^{+}$934.5; Found 934.

C1 salicylhydroxamic acid ester of C20 acetate of C20-epi-salinomycin 22: Yield: $35 \mathrm{mg}$, $17 \%$. Isolated as a white amorphous solid, $>95 \%$ pure by NMR and a single spot by TLC. UVactive and strains green with PMA; ${ }^{1} \mathrm{H}$ NMR $\left(400 \mathrm{MHz}, \mathrm{CD}_{2} \mathrm{Cl}_{2}\right) \delta 11.74(\mathrm{~s}, 1 \mathrm{H}), 11.20(\mathrm{~s}, 1 \mathrm{H})$, $8.33(\mathrm{ddd}, J=9.6,8.1,1.4 \mathrm{~Hz}, 1 \mathrm{H}), 7.41(\mathrm{ddd}, J=8.7,7.3,1.5 \mathrm{~Hz}, 1 \mathrm{H}), 6.96-6.92(\mathrm{~m}, 1 \mathrm{H}), 6.85$ (ddd, $J=8.4,7.3,1.2 \mathrm{~Hz}, 1 \mathrm{H}), 6.42(\mathrm{dd}, J=10.6,2.4 \mathrm{~Hz}, 1 \mathrm{H}), 6.17$ (ddd, $J=10.5,5.4,2.9 \mathrm{~Hz}$, $1 \mathrm{H}), 4.80(\mathrm{~d}, J=5.5 \mathrm{~Hz}, 1 \mathrm{H}), 4.07-3.96(\mathrm{~m}, 2 \mathrm{H}), 3.88(\mathrm{dd}, J=10.1,2.5 \mathrm{~Hz}, 1 \mathrm{H}), 3.77-3.67(\mathrm{~m}$, 2H), $3.49(\mathrm{dd}, J=12.0,2.2 \mathrm{~Hz}, 1 \mathrm{H}), 3.36(\mathrm{t}, J=4.6 \mathrm{~Hz}, 1 \mathrm{H}), 3.17(\mathrm{ddd}, J=15.2,10.5,5.9 \mathrm{~Hz}$, 1H), 3.01-2.91 (m, 1H), 2.62-2.55 (m, 1H), 2.30-0.50 (m, 58H) ppm; ${ }^{13} \mathrm{C}$ NMR (101 MHz, $\left.\mathrm{CD}_{2} \mathrm{Cl}_{2}\right) \delta 216.5,173.6,170.2,168.6,161.9,134.9,127.8,126.8,126.3,126.1,118.9,118.1,112.0$ 106.2, 98.8, 90.2, 80.0, 76.9, 75.1, 73.4, 72.2, 71.1, 68.8, 67.4, 46.5, 46.2, 40.1, 38.6, 37.2, 36.8, $32.8,31.0,30.9,29.9,28.5,26.7,26.1,23.5,22.3,21.0,20.0,17.2,16.7,16.3,15.0,14.8,14.6$, 11.9, 11.0, 8.0, 6.7 ppm; FT-IR (KBr tablet): 3517 (br, m), 3301 (br, m), 2963 (s), 2933 (s), 2875 (m), 1787 (s), $1744(\mathrm{~s}), 1703$ (s), 1650 (s), 1609 (m), 1565 (w), 1510 (m), 1481 (m), 1457 (m), $1367(\mathrm{~m}) \mathrm{cm}^{-1}$; ESI MS (m/z): $[\mathrm{M}+\mathrm{Na}]^{+}$Calcd for $\mathrm{C}_{51} \mathrm{H}_{77} \mathrm{NNaO}_{14}{ }^{+} 950.5$; Found 950.

\subsection{In vitro biological studies}

The protocols for the cultivation of bloodstream form of T. brucei 427-221a [30] and human myeloid HL-60 cells [31], the screening assay, and the swelling experiments can be found either in the Supplementary material or in the reference literature [9,18,26-27].

\section{Supporting Information}


Additional figures presenting the NMR and ESI MS spectra of the newly synthesized derivatives of salinomycin are freely available via the Internet at http://xxx.

\section{Acknowledgments}

M.A. wishes to acknowledge the Polish Science Center (NCN) for financial support through a SONATA grant (2016/23/D/ST5/00242). M.A. also wishes to acknowledge the NCN and the Polish National Agency for Academic Exchange (NAWA) for scholarships under the UWERTURA (2019/32/U/ST4/00092) and the BEKKER program (PPN/BEK/2019/1/00034), respectively, and the Polish Ministry of Science and Higher Education (MNiSW) for a scholarship for outstanding young scientists for the period 2020-2023 (STYP/15/1665/E-336/2020).

D.C. wishes to acknowledge the scholarship no. POWR. 03.02.00-00-I026/16, co-financed by the European Union through the European Social Fund under the Operational Program Knowledge Education Development. D.C. also wishes to acknowledge the NCN for the doctoral scholarship ETIUDA (2020/36/T/ST4/00041).

\section{References}

[1] M. Antoszczak, D. Steverding, A. Huczyński, Anti-parasitic activity of polyether ionophores, Eur. J. Med. Chem. 166 (2019) 32-47.

[2] M. Antoszczak, A comprehensive review of salinomycin derivatives as potent anticancer and anti-CSCs agents, Eur. J. Med. Chem. 166 (2019) 48-64.

[3] D.A. Kevin II, D.A. Meujo, M.T. Hamann, Polyether ionophores: Broad-spectrum and promising biologically active molecules for the control of drug-resistant bacteria and parasites, Expert Opin. Drug Discov. 4 (2009) $109-146$.

[4] M. Antoszczak, A. Huczyński, Salinomycin and its derivatives - A new class of multiple-targeted "magic bullets", Eur. J. Med. Chem. 176 (2019) 208-227. 
[5] P.B. Gupta, T.T. Onder, G. Jiang, K. Tao, C. Kuperwasser, R.A. Weinberg, E.S. Lander, Identification of selective inhibitors of cancer stem cells by high-throughput screening, Cell 138 (2009) 645-659.

[6] C. Naujokat, R. Steinhart, Salinomycin as a drug for targeting human cancer stem cells, J. Biomed. Biotechnol. 2012 (2012) 950658.

[7] M. Antoszczak, A medicinal chemistry perspective on salinomycin as a potent anticancer and anti-CSCs agent, Eur. J. Med. Chem. 164 (2019) 366-377.

[8] S.V. Barrett, M.P. Barrett, Anti-sleeping sickness drugs and cancer chemotherapy, Parasitol, Today Off. 16 (2000) 7-9.

[9] D. Steverding, M. Antoszczak, A. Huczyński, In vitro activity of salinomycin and monensin derivatives against Trypanosoma brucei, Parasit. Vectors 9 (2016) 409-414.

[10] D. Steverding, Sleeping sickness and nagana disease caused by Trypanosoma brucei, in: C. Marcondes (Ed.), Arthropod Borne Diseases, Springer, Cham, 2017.

[11] J.R. Franco, P.P. Simarro, A. Diarra, J.G. Jannin, Epidemiology of human African trypanosomiasis, Clin. Epidemiol. 6 (2014) 257-275.

[12] A. Stich, P.M. Abel, S. Krishna, Human African trypanosomiasis, BMJ 325 (2002) 203-206.

[13] D. Steverding, The history of African trypanosomiasis, Parasit. Vectors 1 (2008) 3.

[14] World Health Organization - Trypanosomiasis, human African (sleeping sickness) [on-line access: 2020-0526].

[15] V. Delespaux, H.P. de Koning, Drugs and drug resistance in African trypanosomiasis, Drug Resist. Updates 10 (2007) 30-50.

[16] A.H. Fairlamb, Chemotherapy of human African trypanosomiasis: Current and future prospects, Trends Parasitol. 19 (2003) 488-494.

[17] E. Matovu, T. Seebeck, J.C. Enyaru, R. Kaminsky, Drug resistance in Trypanosoma brucei ssp., the causative agents of sleeping sickness in man and nagana in cattle, Microb. Infect. 3 (2001) 763-770.

[18] M. Antoszczak, D. Steverding, M. Sulik, J. Janczak, A. Huczyński, Anti-trypanosomal activity of doubly modified salinomycin derivatives, Eur. J. Med. Chem. 173 (2019) 90-98. 
[19] D. Czerwonka, A. Urbaniak, S. Sobczak, S. Piña-Oviedo, T.C. Chambers, M. Antoszczak, A. Huczyński, Synthesis and anticancer activity of tertiary amides of salinomycin and their C20-oxo analogues, ChemMedChem 15 (2020) 236-246.

[20] A. Urbaniak, M. Delgado, M. Antoszczak, A. Huczyński, T.C. Chambers, Salinomycin derivatives exhibit activity against primary acute lymphoblastic leukemia (ALL) cells in vitro, Biomed. Pharmacother. 99 (2018) 384-390.

[21] M. Antoszczak, K. Popiel, J. Stefańska, J. Wietrzyk, E. Maj, J. Janczak, G. Michalska, B. Brzezinski, A. Huczyński, Synthesis, cytotoxicity and antibacterial activity of new esters of polyether antibiotic salinomycin, Eur. J. Med. Chem. 76 (2014) 435-444.

[22] M. Antoszczak, E. Maj, J. Stefańska, J. Wietrzyk, J. Janczak, B. Brzezinski, A. Huczyński, Synthesis, antiproliferative and antibacterial activity of new amides of salinomycin, Bioorg. Med. Chem. Lett 24 (2014) $1724-1729$.

[23] W. Zhang, J. Wu, B. Li, J. Xia, H. Wu, L. Wang, J. Hao, Q. Zhou, S. Wu, Synthesis and biological activity evaluation of 20-epi-salinomycin and its 20-O-acyl derivatives, RSC Adv. 6 (2016) 41885.

[24] B. Borgström, X. Huang, M. Pošta, C. Hegardt, S. Oredsson, D. Strand, Synthetic modification of salinomycin: Selective $O$-acylation and biological evaluation, Chem. Commun. 49 (2013) 9944-9946.

[25] Q. Shi, Y. Li, S. Bo, X. Li, P. Zhao, Q. Liu, Z. Yang, H. Cong, H. Deng, M. Chen, S. Chen, X. Zhou, H. Ding, Z.X. Jiang, Discovery of a ${ }^{19} \mathrm{~F}$ MRI sensitive salinomycin derivative with high cytotoxicity towards cancer cells, Chem. Commun. 52 (2016) 5136-5139.

[26] D. Steverding, A. Huczyński, Trypanosoma brucei: Trypanocidal and cell swelling activities of lasalocid acid, Parasitol. Res. 116 (2017) 3229-3233.

[27] K. Merschjohann, F. Sporer, D. Steverding, M. Wink, In vitro effect of alkaloids on bloodstream forms of Trypanosoma brucei and T. congolense, Planta Med. 67 (2001) 623-627.

[28] S. Nwaka, A. Hudson, Innovative lead discovery strategies for tropical diseases, Nat. Rev. Drug Discov. 5 (2006) 941-955.

[29] A. Huczyński, J. Janczak, J. Stefańska, M. Antoszczak, B. Brzezinski, Synthesis and antimicrobial activity of amide derivatives of polyether antibiotic - salinomycin, Bioorg. Med. Chem. Lett. 22 (2012) 4697-4702. 
[30] H. Hirumi, K. Hirumi, J.J. Doyle, G.A.M. Gross, In vitro cloning of animal infective bloodstream forms of Trypanosoma brucei, Parasitology 80 (1980) 371-382.

[31] S.J. Collins, R.C. Gallo, R.E. Gallagher, Continues growth and differentiation of human myeloid leukaemic cells in suspension cultures, Nature 270 (1977) 347-349. 